\section{PERAN OTORITAS JASA KEUANGAN DALAM MELINDUNGI PEMEGANG POLIS ASURANSI AKIBAT PAILITNYA PERUSAHAAN ASURANSI (Studi Putusan Mahkamah Agung Nomor 408 K/Pdt.Sus-Pailit/2015)Abstract \\ Oleh:}

\section{Muhammad Ridho*}

\section{Abstract}

The Financial Services Authority as an institution that oversees activities in the insurance sector functions to create a financial system that grows in a sustainable and stable manner and can foster public confidence in the insurance industry. Within the scope of supervision in the insurance sector, the Financial Services Authority has the authority to submit bankrupt statements to insurance companies in order to protect the interests of insurance policy holders.

The purpose of the research in this thesis is to analyze the authority of the Financial Services Authority in the insolvency of insurance companies, to analyze the legal protection of customers who are harmed by the insolvency statement of insurance company to analyze the legal considerations of judges in the Supreme Court's Decision No. $408 \mathrm{~K} / \mathrm{Pdt}$. Sus-Pailit /2015.

The research method used is descriptive analysis that leads to normative juridical research that is research conducted by referring to legal norms that is examining library materials or secondary materials, and secondary data by processing data from primary legal materials, secondary legal materials and tertiary legal materials.

The results showed that the Authority of the Financial Services Authority in the insolvency of insurance companies is based on the Bankruptcy Law and Suspension of Debt Payment Obligation ('UU KKPU') and Financial Services Authority Act ('UU OJK') with its implementation arrangement and the Financial Services Authority's position as the party submitting an application for bankruptcy statements through the Board of Commissioner of Financial Services Authority. Protection provided to insurance policy holders in the case of bankruptcythat is guaranteed the position of policy holder in the event of bankruptcy to the insurance company.Judge's legal consideration in the decision of the Supreme Court Number 408 KJ Pdt. Sus-Pailit /2015 so as to decide on PT. AsuransiJiwaBumiAsih Jaya declared bankrupt is the OJK as a financial service sector supervisory agency authorized to submit bankruptcy requests for insurance companies because PT AsuransiJiwaBumiAsih Jaya is proven to have debt in the form of payment of the policy holder's claim liability.

Key-Words: Role of OJK, Insurance Policy, Bankruptcy.

\section{Abstrak \\ Otoritas Jasa Keuangan sebagai} lembaga yang mengawasi kegiatan di sektor perasuransian berfungsi untuk mewujudkan sistem keuangan yang tumbuh secara berkelanjutan dan stabil serta dapat menumbuhkan kepercayaan masyarakat terhadap industri asuransi. Dalam lingkup pengawasan di sektor perasuransian, Otoritas Jasa Keuangan mempunyai kewenangan dalam pengajuan permohonan pernyataan pailit terhadap Perusahaan Asuransi dalam rangka melindungi kepentingan pemegang polis asuransi..

Tujuan penelitian dalam tesis ini adalah untuk menganalisis kewenangan Otoritas Jasa Keuangan dalam kepailitan perusahaan asuransi, untuk menganalisis perlindungan hukum terhadap nasabah yang dirugikan akibat pernyataan pailit perusahaan asuransi, untuk menganalisis pertimbangan hukum hakim dalam putusan Mahkamah Agung Nomor 408 K/Pdt.Sus-Pailit/2015.

Metode penelitian yang digunakan adalah deskriftif analisis yang mengarah pada penelitian hukum yuridis normatif yakni penelitian yang dilakukan dengan cara mengacu pada norma-norma hukum yaitu meneliti terhadap bahan pustaka atau bahan sekunder. Data sekunder dengan mengolah data dari bahan hukum primer, bahan hukum sekunder dan bahan hukum tersier.

Hasil penelitian menunjukkan bahwa kewenangan Otoritas Jasa Keuangan dalam kepailitan perusahaan asuransi didasarkan pada UU KPKPU dan UU OJK dengan pengaturan pelaksananya serta kedudukan OJK sebagai pihak yang mengajukan permohonan pernyataan pailit melalui Dewan Komisioner OJK. Perlindungan yang diberikan kepada pemegang polis asuransi dalam kasus 
Media Komunikasi dan Informasi Hukum dan Masyarakat

kepailitan yaitu dijaminnya kedudukan pemegang polis dalam hal terjadi kepailitan terhadap perusahaan asuransi. Pertimbangan hukum hakim dalam putusan Mahkamah Agung Nomor 408 K/Pdt.Sus-Pailit/2015 sehingga memutuskan PT. Asuransi Jiwa Bumi Asih Jaya dinyatakan pailit adalah OJK sebagai lembaga pengawasan sektor jasa keuangan berwenang mengajukan permohonan pailit untuk perusahaan asuransi dikarenakan PT. Asuransi Jiwa Bumi Asih Jaya terbukti mempunyai utang berupa pembayaran kewajiban klaim pemegang polis.

Kata Kunci: Peran OJK, Polis Asuransi, Pailit

\section{PENDAHULUAN}

\section{A. Latar Belakang}

Pasal 27 ayat (2) Undang-Undang Dasar 1945 (UUD 1945 berbunyi: Tiap warga negara berhak atas penghidupan yang layak bagi kemanusiaan. Berdasarkan pasal tersebut, maka setiap warga negara mendapatkan perlindungan terhadap industri perasuransian yang sehat, dapat diandalkan, amanah, dan kompetitif akan meningkatkan pelindungan bagi pemegang polis, tertanggung, atau peserta, dan berperan mendorong pembangunan nasional.

Manusia dalam menjalani kehidupan dan melakukan berbagai kegiatannya, selalu dihadapkan pada berbagai kemungkinan keadaan yang tidak pasti. Keadaan tidak pasti terhadap setiap kemungkinan yang dapat terjadi baik dalam bentuk atau peristiwa yang belum tertentu menimbulkan rasa tidak aman yang lazim disebut resiko. ${ }^{1}$ Risiko ini mungkin berasal dari faktor ekonomi, faktor alam, atau faktor manusia. Risiko ini menimbulkan beban kerugian terhadap harta kekayaan ataupun jiwa manusia itu sendiri. ${ }^{2}$

1 Sri Rezeki Hartono, Hukum Asuransi dan Perusahaan Asuransi, Sinar Grafika, Jakarta, 2005, hlm. 2

${ }^{2}$ A. Junaedy Ganie, Hukum Asuransi Indonesia, Sinar Grafika, Jakarta, 2011 hlm.8.
Risiko merupakan aspek utama dari kehidupan manusia pada umumnya dan merupakan faktor penting dalam asuransi. Risiko merupakan kemungkinan penyimpangan harapan yang tidak menguntungkan, yaitu ketidak pastian suatu peristiwa yang tidak diinginkan. ${ }^{3}$ Arti dan pengertian risiko sebenarnya sangat luas, mengingat sangat luasnya ruang lingkup tentang risiko, namun dapat dipahami kriteria atau ciri risiko dalam asuransi sebagai berikut :

1. Bahaya yang mengancam benda atau objek asuransi.

2. Berasal dari faktor ekonomi, alam atau manusia.

3. Diklasifikaikan menjadi risiko pribadi, kekayaan, tanggung jawab.

4. Hanya berpeluang menimbulkan kerugian. ${ }^{4}$

Timbulnya suatu risiko menjadi kenyataan merupakan suatu yang belum pasti, sementara kemungkinan bagi seseorang akan mengalami kerugian atau kehilangan yang dihadapi oleh setiap manusia merupakan suatu hal yang tidak diinginkan. Oleh karena itu, kemungkinan timbulnya suatu risiko menjadi kenyataan, adalah suatu hal yang diusahakan untuk tidak terjadi tetapi saat terjadi suatu hal yang tidak diinginkan dan mengalami suatu kerugian akibat kejadian tersebut, tentu saja manusia akan menanggung kerugian tersebut. ${ }^{5}$

Manusia selalu berusaha mencari jalan dengan cara mencari pihak lain untuk mau mengambil alih ancaman tersebut. Usaha dan upaya manusia untuk menghindari dan melimpahkan resikonya kepada orang lain beserta proses pelimpahan sebagai suatu

\footnotetext{
${ }^{3}$ Sri Rezeki Hartono, Op.Cit., hlm.4

4 Abdulkadir Muhammad, Hukum Asuransi Indonesia, Citra Aditya Bakti, Bandung, 2015, hlm. 118.

${ }^{5}$ Ibid., hlm.5
} 
Media Komunikasi dan Informasi Hukum dan Masyarakat

kegiatan itulah yang merupakan embrio atau cikal bakal perasuransian yang dikelola sebagai suatu kegiatan ekonomi yang rumit sampai saat ini. ${ }^{6}$

Mengambil alih risiko yang tidak diinginkan di masa yang akan datang, maka diperlukan perusahaan yang mau menanggung risiko tersebut yaitu perusahaan asuransi yang mau dan sanggup menanggung setiap risiko yang akan dihadapi nasabahnya baik perorangan maupun badan usaha. Hal ini disebabkan perusahaan asuransi merupakan perusahaan yang melakukan usaha pertanggungan terhadap risiko yang akan dihadapi nasabahnya. ${ }^{7}$

Asuransi merupakan salah satu bentuk pengalihan risiko. Pertimbangan yang timbul dalam pengambilan keputusan terhadap bentuk penanganan risiko didasarkan pada apakah risiko yang berhasil diidentifikasi karena ketidak pastian tersebut dapat dicegah, dihindari, ditanggung sendiri atau harus dialihkan kepada pihak lain. Perjanjian anatara penanggung dan tertanggung sebagai suatu perjanjian asuransi atas kejadian yang dicatumkan dalam perjanjian yang timbul tidak dapat dipastikan, ini tidak membatasi kejadian yang diperjanjikan. Oleh karena itu, diperlukan kejelasan tentang risiko yang dihadapi oleh tertanggung yang akan diambil alih oleh penanggung dengan imbalan pembayaran premi. $^{8}$

Tuntutan kebutuhan terhadap pertanggungan asuransi terus berkembang mengikuti tingkat kompleksitas risiko yang timbul dan mengancam pribadi maupun dunia

\footnotetext{
${ }^{6}$ Sri Rezeki Hartono, Op.Cit, hlm.3

${ }^{7}$ Abdulkadir Muhamad, Op.Cit, hlm.120.

8 Mulya Nasution, Asuransi Dan Usaha Perasuransian Di Indonesia, Alfabeta, Bandung, 2013, hlml. 3.
}

usaha. Perlindungan jasa asuransi dalam mengatasi risiko telah melahirkan usaha perasuransian sebagai suatu bisnis. Industri asuransi dapat memegang peranan penting bagi perekonomian suatu bangsa dalam bentuk penyediaan jasa pengambil alihan risiko, sehingga memungkinkan pribadi atau pelaku usaha membuat suatu perancanaan yang baik untuk perlindungan mereka terhadap resiko yang timbul dari ketidakpastian. ${ }^{9}$

Undang-Undang Nomor 40 Tahun 2014 tentang Perasuransian (selanjutnya disebut UU Perasuransian) menyebutkan bahwa usaha perasuransian hanya dapat dilakukan oleh Perseroan Terbatas, Koperasi, Usaha Bersama yang telah ada pada saat Undang-Undang ini diundangkan.Tentunya di dalam menjalankan kegiatan usahanya perusahaan-perusahaan tersebut dapat mengalami resiko yaitu seperti resiko mengalami pailit, dibalik perlindungan akan rasa aman yang diberikan dari jasa asuransi, perusahaan asuransi seperti halnya perusahaan lainnya tidak terlepas dari ancaman pailit. Perusahaan asuransi tidak selalu berjalan dengan mulus. Perusahaan asuransi bisa pailit kapan saja apabila manajemen perusahaan asuransi tidak berjalan dengan baik. Untuk itu diperlukan sebuah manajemen yang dapat mengelola atau mengolah harta kekayaan perusahaan asuransi dengan baik. ${ }^{10}$

Kepailitan merupakan suatu keadaan debitor yang tidak mampu untuk melakukan pembayaran terhadap utang-utang kepada para kreditornya. Keadaan tidak mampu membayar lazimnya disebabkan oleh suatu

${ }^{9}$ Ibid., hlm.5

${ }^{10}$ Man Suparman dan Endang, Hukum Asuransi: Perlindungan Tertanggung Asuransi Deposito Usaha Perasuransian, Alumni, Bandung, 2007, hlm. 11. 
Media Komunikasi dan Informasi Hukum dan Masyarakat

kondisi kesulitan keuangan (financial distress) dan usaha debitur yang telah mengalami kemunduran. ${ }^{11}$

Konsekuensi hukum dari pernyataan pailit, maka dilakukan penyitaan terhadap semua kekayaan debitor yang ada pada saat pailit dan kekayaan yang diperoleh selama berada dalam kepailitan. Inilah yang dinamakan sita umum public attacment). ${ }^{12}$ Pengurusan dan pemberesan harta pailit selanjutnya dilakukan oleh Balai Harta Peninggalan (BHP) yang berada di bawah pengawasan hakim pengawas yang diangkat secara bersamaan oleh Pengadilan Niaga pada saat putusan pernyataan pailit terhadap debitor.

Tujuan utama kepailitan adalah untuk melakukan pembagian antara para kreditor atas kekayaan debitur oleh kurator. Kepailitan dimaksudkan untuk menghindari terjadinya sitaan terpisah atau eksekusi terpisah oleh kreditor dan menggantikannya dengan mengadakan sitaan bersama sehingga kekayaan debitur dapat dibagikan kepada semua kreditor sesuai dengan hak masingmasing.

Apabila seorang debitur telah secara resmi dinyatakan pailit maka secara yuridis akan menimbulkan akibat-akibat sebagai berikut:

1. Debitur kehilangan segala haknya untuk menguasai dan mengurus atas kekayaan harta bendanya (asetnya), baik menjual, menggadai, dan lain sebagainya, serta segala sesuatu yang diperoleh selama kepailitan sejak tanggal putusan pernyataan pailit diucapkan.

\footnotetext{
${ }^{11}$ Titik Tejaningsih, Perlindungan Hukum Terhadap Kreditor Separatis dalam Pengurusan dan Pemberasan Harta Pailit, Program Doktor (S-3) IImu HukumProgram Pascasarjana Fakultas Hukum Universitas Islam Indonesia, Yogyakarta, 2015, hIm.1

12 Man HS. Sastrawidjaja, Hukum Kepailitan dan Penundaan Kewajiban Pembayaran Utang, Alumni, Bandung, 2006, hlm.78
}

2. Utang-utang baru tidak lagi dijamin oleh kekayaannya.

3. Untuk melindungi kepentingan kreditor, selama putusan atas permohonan pernyataan pailit belum diucapkan, kreditor dapat mengajukan permohonan kepada pengadilan untuk :

a. Meletakkan sita jaminan terhadap sebagian atau seluruh kekayaan debitur.

b. Menunjuk kurator sementara untuk mengawasi pengelolaan usaha debitur, menerima pembayaran kepada kreditor, pengalihan atau penggunaan kekayaan debitur (Pasal 10)

4. Harus diumumkan di 2 (dua) surat kabar (Pasal 15 ayat (4). ${ }^{13}$

Akibat hukum bagi debitur setelah dinyatakan pailit adalah ia tidak boleh lagi mengurus harta kekayaannya yang dinyatakan pailit, dan selanjutnya yang akan mengurus harta kekayaan atau perusahaan debitur pailit tersebut adalah kurator. Menjaga dan mengawasi tugas seorang kurator, pengadilan menunjuk seorang Hakim Pengawas, yang mengawasi perjalanan proses kepailitan (pengurusan dan pemberesan harta pailit). ${ }^{14}$

Kedudukan para kreditor dalam kepailitan pada dasarnya adalah sama (paritas creditorium) dan karenanya mereka mempunyai hak yang sama atas hasil eksekusi boedel pailit sesuai dengan besarnya tagihan mereka masing-masing (pari passu pro rata parte). ${ }^{15}$ Asas tersebut mengenal pengecualian yaitu golongan kreditor yang memegang hak agunan atas kebendaan dan golongan kreditor yang haknya didahulukan (kreditor separatis)

${ }^{13}$ Abdul R. Saliman dkk, Hukum Bisnis Untuk Perusahaan; Teori dan Contoh Kasus, Renada Media Grup, Jakarta, 2005, hlm.153

14 Sunarmi, Hukum Kepailitan, USU Press, Medan, 2009, hlm. 16

${ }_{15}$ Ivida Dewi Amrih Suci dan Herowati Poesoko, Hukum Kepailitan Kedudukan dan Hak Kreditor Separatis atas Benda Jaminan Deitor Pailit, LaksBang Pressindo, Yogyakarta, 2016, hlm.97. 
Media Komunikasi dan Informasi Hukum dan Masyarakat

berdasarkan undang-undang kepailitan dan peraturan perundang-undangan lainnya.

Adapun golongan kreditor dalam

kepailitan adalah :

1. Kreditor separatis yaitu kreditor yang dapat menjual sendiri benda jaminan seolah-olah tidak terjadi kepailitan. Dapat dikatakan sebagai kreditor yang tidak terkena akibat kepailitan. Artnya para kreditor separatis ini dapat melaksanakan hak-hak eksekusinya meskipun debitornya telah dinyatakan pailit. Tergolong sebagai kreditor separatis adalah kreditor pemegang gadai, jaminan fidusia, hak tanggungan atau hak agunan atas kebendaan lainnya. Dari hasil penjualan benda-benda jaminan tersebut, kreditor akan mengambil pelunasan atas piutangnya dan sisanya akan dikembalikan pada boedel pailit. Apabila ternyata hasil penjualan benda jaminan itu kurang dari jumlah piutangnya, maka kreditor ini akan menggabungkan diri dengan kreditor lain sebagai kreditor konkuren.

2. Kreditor preferen/istimewa yaitu golongan kreditor yang piutangnya mempunyai kedudukan istimewa, artinya kreditor ini mempunyai hak untuk mendapat pelunasan terlebih dahulu dari hasil penjualan boedel pailit. Kreditor preferen ini oleh undang-undang diberi tingkatan yang lebih tinggi dari kreditor lainnya semata-mata berdasarkan sifat piutang seperti yang diatur dalam Pasal 1133, 1134, 1139 dan 1149 KUHPerdata.

3. Kreditor konkuren yaitu kreditor yang tidak termasuk golongan kreditor separatis atau golongan preferen. Pelunasan piutangpiutang mereka dicukupkan dari sisa hasil penjualan/pelelangan harta pailit sesudah diambil bagian golongan separatis dan golongan preferen. Sisa hasil penjualan harta pailit itu dibagi menurut imbangan besar kecilnya piutang para kreditor konkuren (Pasal 1132 KUHPerdata). ${ }^{16}$

\section{Hak-hak yang melekat pada kreditor}

istimewa dan separatis atas harta debitor dalam kepailitan ditentukan sebagai berikut :

1. Kreditor dengan hak istimewa menurut Pasal 1139 dan Pasal 1149 KUHPerdata, tanpa kehilangan hak yang diberikan kepada mereka untuk menahan kebendaan milik debitor yang diberikan oleh undang-undang.

2. Kreditor dengan jaminan kebendaan berepa gadai hipotek, hak atas panenan, hak tanggungan dan jaminan fidusia, tanpa kehilangan hak untuk menjual dan

16 Sunarmi, Hukum Kepailitan Edisi 2, Sofmedia, Jakarta, 2010, hlm.170. memperoleh pelunasan terlebih dahulu dari harta kebendaan debitor yang dijaminkan secara kebendaan dan dijual tersebut. ${ }^{17}$

Selain itu, bagi kedua kreditor tersebut,

berhak untuk setiap saat :

1. Memajukan permohonan pernyataan pailit kepada debitor yang tidak membayar utang atau kewajibannya dalam bentuk penyerahan sejumlah uang tertentu pada waktu yang telah ditentukan.

2. Dapat disertakan sebagai kreditor kedua dalam setiap permohonan pernyataan paolit yang ditujukan kepada debitor yang tidak memenuhi utang atau kewajibannya dalam bentuk penyerahan sejumlah uang tertentu pada waktu yang ditentukan tersebut. ${ }^{18}$

\section{Pasal 52 UU Perasuransian}

memberikan sinyal adanya perlindungan terhadap pemegang polis, pada pasal itu disebutkan bahwa :

1. Dalam hal perusahaan asuransi, perusahaan asuransi syariah, perusahaan reasuransi atau perusahaan reasuransi syariah dipailitkan atau dilikuidasi, hak pemegang polis, tertanggung atau peserta atas pembagian harta kekayaan mempunyai kedudukan yang lebih tinggi dari pihak lainnya.

2. Dalam hal perusahaan asuransi atau perusahaan reasuransi dipailitkan atau dilikuidasi, dana asuransi harus digunakan terlebih dahulu untuk memenuhi kewajiban kepada pemegang polis, tertanggung atau pihak lain yang berhak atas manfaat asuransi. ${ }^{19}$

Berdasarkan pada ketentuan pasal tersebut, dalam kasus perusahaan asuransi mengalami kepailitan, maka kedudukan pemegang polis merupakan kreditor preferen. Kreditor preferen merupakan kreditor yang oleh undang-undang, semata-mata karena sifat piutangnya, mendapatkan pelunasan terlebih dahulu. Kreditor preferen merupakan kreditor

${ }^{17}$ Emmy Yuhassarie, Undang-Undang Kepailitan dan Perkembangannya, Pusat Pengkajian Hukum, Jakarta, 2004, hlm.174-175.

18 lbid.

${ }^{19}$ Ivida Dewi Amrih Suci dan Herowati Poesoko, Op.Cit., hlm. 39. 
Media Komunikasi dan Informasi Hukum dan Masyarakat

yang mempunyai hak istimewa, yaitu suatu hak yang oleh undang-undang diberikan kepada seorang berpiutang sehingga tingkatnya lebih tinggi daripada orang berpiutang lainnya, berdasarkan sifat piutangnya sebagaimana disebutkan dalam Pasal 1134 Ayat (1) KUHPerdata, peraturan mengenai Kreditor Preferen diatur dalam 1139-1149 KUHPerdata. ${ }^{20}$

Ditetapkannya suatu perusahaan dalam keadaan pailit berarti bahwa kekayaan debitor akan berada di bawah sita umum dan debitor demi hukum telah kehilangan hak untuk menguasai dan mengurus kekayaan karena dianggap tidak mampu lagi. Kepailitan pada sebuah perusahaan dapat terjadi karena ketidakmampuan perusahaan asuransi tersebut dalam melunasi klaim dari nasabah yang sudah jatuh tempo, maka saat terjadi perusahaan asuransi pailit pihak yang dirugikan adalah nasabah karena tidak dapat meminta pembayaran klaim, sesuai Pasal 50 Ayat (1) UU Perasuransian menyatakan Permohonan pernyataan pailit terhadap Perusahaan Asuransi, Perusahaan Asuransi Syariah, Perusahaan Reasuransi, atau Perusahaan Reasuransi Syariah berdasarkan undang-undang ini hanya dapat diajukan oleh Otoritas Jasa Keuangan (selanjutnya disebut OJK). ${ }^{21}$

UU Perasuransian memuat kewenangan ekslusif yang dimiliki OJK, apabila seorang ingin mengajukan pailit, jika menyangkut perusahaan asuransi maka kewenangan boleh atau tidaknya ada pada OJK yang dulu ada pada Menteri Keuangan. ${ }^{22}$ Dengan demikian pasca diundangkannya

${ }^{20}$ Ibid., hlm. 41

${ }^{21}$ Amir Syamsudin, Analisis Putusan Mahkamah Konsititusi tentang Kepailitan, Jurnal Konstitusi, Vol. 2 Nomor 2, September, $2017 \mathrm{hlm} .87$

22 lbid., hlm. 89.
Undang-Undang Nomor 21 Tahun 2011 Tentang Otoritas Jasa Keuangan (UU OJK) terjadi peralihan fungsi pengaturan dan pengawasan perusahaan asuransi dari Menteri Keuangan yang beralih ke OJK. Hal ini berdampak pula pada pengajuan permohonan pernyataan pailit terhadap perusahaan asuransi yang juga beralih ke OJK.

OJK telah mencabut izin Perusahaan Asuransi Bumi Asih Jaya. Pencabutan itu dilakukan akibat perusahaan dikabarkan memiliki utang klaim kepada nasabah yang belum dibayar. Dengan dicabutnya izin usaha perusahaan, maka PT Asuransi Jiwa Bumi Asih Jaya dilarang melakukan kegiatan usaha di bidang asuransi jiwa dan diwajibkan menurunkan papan nama, serta menyelesaikan utang dan kewajibannya.

Pencabutan izin usaha Perusahaan Asuransi Bumi Asih Jaya tentu saja nasabah/pemegang polis menjadi pihak yang dirugikan karena tidak bisa meminta claim ataupun pengembalian premi dari perusahaan tersebut, hal ini sungguh mencederai nilai-nilai yang terkandung dalam prinsip Utmost Good Faith (itikad baik) dalam asuransi. ${ }^{23}$

Dewan Komisioner OJK mengeluarkan keputusan Nomor: KEP-112/D.05/2013 pada 18 Oktober 2013 untuk mencabut izin usaha Asuransi Jiwa Bumi Asih Jaya. Berdasarkan keputusan pencabutan izin usaha tersebut, perusahaan asuransi ini seharusnya melaksanakan penyelesaian kewajiban kepada seluruh pemegang polis. Akan tetapi, PT Asuransi Jiwa Bumi Asih Jaya belum melaksanakan keputusan tersebut sehingga OJK mengajukan gugatan pailit kepada PT Asuransi Jiwa Bumi Asih Jaya melalui

23 Man Suparman Sastrawidjadja, Hukum Asuransi: Perlindungan Tertanggung, Asuransi Deposito, Usaha Perasuransian. Op.Cit, hlm 56 
Media Komunikasi dan Informasi Hukum dan Masyarakat

Pengadilan Niaga Jakarta Pusat, sesuai dengan Pasal 51 Ayat (1) UU Perasuansian, Kreditor menyampaikan permohonan kepada OJK untuk mengajukan permohonan pernyataan pailit kepada pengadilan niaga. Kemudian dalam Pasal 51 Ayat (2) menyebutkan, OJK menyetujui atau menolak permohonan yang disampaikan oleh kreditor sebagaimana dimaksud pada Ayat (1) paling lama 30 (tiga puluh) hari sejak permohonan diterima secara lengkap.

Mahkamah Agung mengeluarkan Nomor 1016 K/Pdt.Sus-Pailit/2016 bahwa mengenai permohonan pernyataan pailit terhadap PT Asuransi Bumi Asih Jaya (PT AJ BAJ) oleh OJK sebagai pemohon pailit. Putusan tersebut menyatakan bahwa permohonan pailit dari pemohon pailit dikabulkan serta menyatakan PT Asuransi Jiwa Bumi Asih Jaya pailit. Dengan pailitnya suatu perusahaan bukan berarti menghilangkan kewajiban Perusahaan untuk mengembalikan premi yang telah dibayarkan oleh pemegang polis karena hal tersebut akan merugikan para pemegang polis.

Berdasarkan hal tersebut di atas sangat menarik untuk diteliti lebih lanjut, sehingga diperlukan kajian hukum yang utuh mengenai kedudukan kreditor separatis dalam kepailitan, maka melalui serangkaian penelitian, bermaksud untuk melakukan penelitian dengan judul : "Peran Otoritas Jasa Keuangan Dalam Melindungi Pemegang Polis Asuransi Akibat Pailitnya Perusahaan Asuransi (Studi Putusan Mahkamah Agung Nomor 408 K/Pdt.Sus-Pailit/2015)".

\section{B. Rumusan Masalah}

Berdasarkan uraian pada latar belakang di atas, maka permasalahan yang akan diteliti dibatasi sebagai berikut:

1. Bagaimana kewenangan Otoritas Jasa Keuangan dalam kepailitan perusahaan asuransi ?

2. Bagaimana perlindungan hukum terhadap nasabah yang dirugikan akibat pernyataan pailit perusahaan asuransi ?

\section{Tujuan Penelitian}

Adapun tujuan penelitian dalam penulisan tesis ini adalah sebagai berikut :

1. Untuk menganalisis kewenangan Otoritas Jasa Keuangan dalam kepailitan perusahaan asuransi.

2. Untuk menganalisis perlindungan hukum terhadap nasabah yang dirugikan akibat pernyataan pailit perusahaan asuransi.

3. Untuk menganalisis pertimbangan hukum hakim dalam putusan Mahkamah Agung Nomor 408 K/Pdt.Sus-Pailit/2015.

\section{Kegunaan/Manfaat Penelitian}

Penelitian ini memiliki manfaat teoritis dan praktis. Adapun kedua kegunaan tersebut adalah sebagai berikut:

1. Secara teoritis, hasil penelitian ini dapat dijadikan sebagai bahan kajian lebih lanjut bagi para akademisi maupun masyarakat umum untuk melahirkan berbagai konsep kajian yang dapat memberikan masukan bagi pembangunan ilmu hukum khususnya tentang peran Otoritas Jasa Keuangan dalam melindungi pemegang polis asuransi akibat pailitnya perusahaan asuransi.

2. Secara praktis, hasil penelitian ini juga dapat digunakan: 
Media Komunikasi dan Informasi Hukum dan Masyarakat

a. Sebagai pedoman dan masukan bagi pemerintah/badan legislatif dalam menentukan kebijakan maupun regulasi dalam upaya pengembangan hukum nasional kearah pengaturan peran Otoritas Jasa Keuangan dalam melindungi pemegang polis asuransi akibat pailitnya perusahaan asuransi dalam bentuk undang-undang khusus atau pembentukan peraturan pelaksanaannya.

b. Penelitian ini dapat memberi masukan bagi para praktisi peradilan yang terlibat langsung dalam proses pelaksanaannya, bagi para kreditor dan debitor pada khususnya dan masyarakat pada umumnya, lembaga kepailitan dan lain-lain.

\section{E. Keaslian Penelitian}

Berdasarkan pemeriksaan yang telah dilakukan oleh peneliti di perpustakaan Universitas Islam Sumatera Utara diketahui bahwa penelitian tentang "'Peran Otoritas Jasa Keuangan Dalam Melindungi Pemegang Polis Asuransi Akibat Pailitnya Perusahaan Asuransi (Studi Putusan Mahkamah Agung Nomor 408 K/Pdt.Sus-Pailit/2015)" belum pernah dilakukan penelitian. Ada beberapa penelitian yang berkaitan dengan topik dalam tesis ini antara lain:

1. Herlina Sihombing dengan judul tesis : Kedudukan Kreditor Separatis Ditinjau Dari Undang-Undang Kepailitan Dikaitkan Dengan Objek Hak Tanggungan. Permasalahan dalam tesis tersebut adalah : a. Bagaimana pengaruh kepailitan terhadap objek hak tanggungan dalam praktek pelaksanaan eksekusi ?

b. Bagaimana Undang-Undang Kepailitan memberikan jaminan kepastian hukum terhadap pelaksanaan pelunasan piutang kreditor separatis yang dijamin dengan hak tanggungan dari debitor yang dinyatakan pailit?

2. Julita $\mathrm{Br}$. Sagala dengan judul tesis : Perlindungan Hukum Bagi Kreditor Separatis Terhadap Tindakan-Tindakan Dalam Periode Keadaan Diam (Standstil) Dalam Kepailitan. Permasalahan dalam tesis tersebut adalah :

a. Bagaimana keadaan diam (standstill) diatur dalam hukum kepailitan Indonesia?

b. Bagaimanakah pelaksanaan keadaan diam (standstill) dalam pengurusan dan pemberesan harta pailit di Balai Harta Peninggalan Medan?

C. Apakah peraturan tentang keadaan diam (standstill) dalam UndangUndang Nomor 37 Tahun 2004 telah memberikan perlindungan hukum bagi kreditor separatis.

3. Zulfikar dengan judul tesis : Efektivitas Perlindungan Hukum Terhadap Para Kreditor Dalam Hukum Kepailitan. Permasalahan dalam tesis tersebut adalah:

a. Bagaimana golongan kreditor dalam hukum kepailitan dan

b. Bagaimana kedudukan para kreditor dalam kepailitan?

c. Bagaimanakah efektivitas perlindungan hukum terhadap para kreditor?

Dilihat dari titik permasalahan yang telah dilakukan pada penelitian sebelumnya 
Media Komunikasi dan Informasi Hukum dan Masyarakat

terdapat adanya perbedaan khususnya pada permasalahan yang akan dibahas dalam penelitian ini. Dengan demikian penelitian dapat dipertanggung jawabkan kebenarannya secara ilmiah atau secara akademik.

\section{F. Kerangka Teori dan Konsepsi}

\section{Kerangka Teori}

Kerangka teori merupakan teori yang dibuat untuk memberikan gambaran yang sistematis mengenai masalah yang akan diteliti. Teori ini masih bersifat sementara yang akan dibuktikan kebenarannya dengan cara meneliti secara realitas. Kerangka teoritis lazimnya dipergunakan dalam penelitian ilmu-ilmu sosial dan juga dapat dipergunakan dalam penelitian hukum, yaitu pada penelitian hukum sosiologis atau empiris. ${ }^{24}$ Sedangkan teori hukum merupakan suatu keseluruhan pernyataan yang saling berkaitan dengan sistim konseptual aturanatuiran hukum dan putusan-putusan hukum dan sistim tersebut untuk sebagian yang penting untuk dipositifkan. ${ }^{25}$ Teori juga sangat diperlukan dalam penulisan karya ilmiah dalam tatanan hukum positif konkrit. ${ }^{26}$

Prinsip dasar teori yang dikutip dalam penelitian ini berpedoman pada objek penelitian yang diteliti, hal ini dilakukan agar penggunaan teori dalam landasan berfikir akan tetap sesuai dengan judul yang ditentukan. Pengutipan teori dalam penyusunan penelitian ini

24 Soerjono Soekanto, Pengantar Penelitian Hukum, UI Press, Jakarta, 1986, hlm. 127

25 J.J. H. Bruggink, Refleksi Tentang Hukum, Citra Aditya Bakti, Bandung, 1999, hlm. 160

${ }_{26}$ Sedarmayanti \& Syarifudin Hidayat, Metodologi Penelitian, Mandar Maju, Bandung, 2002, hlm. 43 disesuaikan dengan rumusan masalah.

Dalam membahasa rumusan masalah peneleitian ini digunakan beberapa teori sebagaimana dikemukakan berikut ini :

a. Teori keadilan.

Teori Keadilan dikemukakan oleh John Rawls sebagai dikutip oleh Mohamad Arifin menyaratkan dua prinsip keadilan sosial yang sangat mempengaruhi pemikiran abad ke-20 yaitu prinsip-prinsip sebagai berikut :

1) Paling utama adalah prinsip kebebasan yang sama (Equal Liberty) yakni setiap orang memiliki hak atas kebebasan individual (liberty) yang sama dengan hak orang lainnya.

2) Prinsip kesempatan yang sama (equal oppurtunity). Dalam hal ini, ketidakadilan ekonomi dalam masyarakat harus diatur untuk melindungi pihak yang tidak beruntung dengan jalan memberi kesempatan yang sama bagi semua orang dengan persyaratan yang adil baik secara sengaja maupun tidak sengaja, artinya meskipun bukan kesalahannya tetap bertanggung jawab atas kerugian yang timbul akibat perbuatannya ${ }^{27}$

Teori mengenai keadilan menurut Aristoteles ialah perlakuan yang sama bagi mereka yang sederajat di depan hukum, tetap menjadi urusan tatanan politik untuk menentukan siapa yang harus diperlakukan sama atau sebaliknya. ${ }^{28}$ Pendapat yang sama juga dikemukakan oleh Satjipto Rahardjo, dalam pembuatan hukum fungsinya sebagai pengatur kehidupan bersama manusia, oleh karena itu hukum harus melibatkan aktifitas dengan kualitas yang berbeda-beda. Pembuatan hukum merupakan awal dari bergulirnya proses pengaturan tersebut, ia

${ }^{27}$ Mohamad Arifin, Teori Dan Filsafat Hukum. RajaGrafindo Persada, Jakarta, 2003, hlm.23

${ }^{28}$ Lawrence. M. Friedman, American Law an Introduction, Terjemahan Wisma Bhakti, Tata Nusa, Jakarta, 2001, hlm. 4 
Media Komunikasi dan Informasi Hukum dan Masyarakat

merupakan momentum yang dimiliki keadaan tanpa hukum dengan keadaan yang diatur oleh hukum. Dia juga mengatakan hukum sebagai perwujudan nilai-nilai yang mengandung arti, bahwa kehadirannya adalah untuk melindungi dan memajukan nilai-nilai yang ada dalam masyarakat. ${ }^{29}$

Berkaitan dengan hal tersebut, maka Undang-Undang Nomor 37 Tahun 2004 tentang Kepailitan dan Penundaan Kewajiban Pembayaran Utang (selanjutnya disebut UU KPKPU) harus sejalan dengan tujuan pembangunan hukum, yaitu dapat melindungi kreditor. Hal tersebut sebagaimana teori etis yang dikemukakan oleh Aristoteles tentang tujuan hukum, yang dikutip dari Van Apeldoorn bahwa hukum semata-mata bertujuan untuk mewujudkan keadilan. ${ }^{30}$ Tujuannya adalah memberikan tiap-tiap orang apa yang patut diterimanya. Keadilan tidak boleh dipandang sebagai penyamarataan. "Keadilan bukan berarti bahwa tiap-tiap orang memperoleh bagian yang sama". ${ }^{31}$ Hukum yang tidak adil dan tidak dapat diterima akal, yang bertentangan dengan norma alam, tidak dapat disebut sebagai hukum, tetapi hukum yang menyimpang.

Keadilan yang demikian ini dinamakan keadilan distributif, yaitu keadilan yang memberikan kepada tiap-tiap orang jatah menurut jasanya. la tidak menuntut supaya tiap-tiap orang mendapat bagian yang sama banyaknya, bukan persamaan melainkan sesuai/sebanding. Keadilan tersebut harus memberikan kepastian hukum dan untuk mencapainya harus memiliki itikad baik karena

29 Satjipto Rahardjo, Sosiologi Hukum : Perkembangan, Metode dan Pilihan Hukum, Universitas Muhamadyah, Surakarta, 2004, hlm. 60.

30 Van Apeldoorn, Pengantar IImu Hukum Pradnya Paramita, Jakarta, 1999, hlm. 53 31 lbid. salah satu tujuan hukum bertugas menjamin adanya kepastian hukum dalam pergaulan manusia, karena meniadakan keadilan berarti menyamakan hukum dengan kekuasaan.

UU KPKPU mengatur mengenai bagaimana cara menentukan kebenaran mengenai adanya (eksistensi) suatu piutang (tagihan) seorang kreditor, mengenai sahnya piutang (tagihan) tersebut, mengenai jumlah yang pasti dari piutang (tagihan) tersebut atau bagaimana tata cara melakukan pencocokan/verifikasi.

b. Teori Kepasatian Hukum

Teori ini dikemukakan dengan tujuan untuk membahas dan menganalisis konsep utang berkenaan dengan kekaburan norma (vague van norm) mengenai frase "tidak membayar" yang terdapat pada Pasal 2 ayat (1) Undang-Undang Nomor 37 Tahun $2004 .^{32}$ Kekaburan norma tersebut dikarenakan pengertian "tidakk membayar" dapat berarti tidak dapat membayar atau tidak mau membayar. Tidak mau membayaar dan tidak mampu membayar merupakan dua hal yang berbeda. Tidak mau membayar berkenaan dengan sikap dan keputusan bertindak untuk tidak mau membayar dikarenakan alasanalasan tertentu. Sikap tidak mau membayar tersebut mungkin saja terjadi dalam keadaan debitor mampun ataupun tidak mampu membayar. Sedangkan dalam hal tidak mampu membayar merupakan suatu keadaan ketidakmampuan untuk membayar yang umumnya disebabkan oleh permasalahan keuangan yang mengalami keerugian atau kebangkrutan sekalipun sadar akan keharusan untuk membayar. ${ }^{33}$

\footnotetext{
${ }^{32}$ Titik Tejdaningish, Op.Cit, hlm.32.

${ }^{33}$ lbid.
} 
Media Komunikasi dan Informasi Hukum dan Masyarakat

Teori Kepastian hukum mengandung 2 (dua) pengertian yaitu pertama adanya aturan yang bersifat umum membuat individu mengetahui perbuatan apa yang boleh atau tidak boleh dilakukan, dan kedua berupa keamanan hukum bagi individu dari kesewenangan pemerintah karena dengan adanya aturan hukum yang bersifat umum itu individu dapat mengetahui apa saja yang boleh dibabankan atau dilakukan oleh Negara terhadap individu. Kepastian hukum bukan hanya berupa pasal-pasal dalam undangundang melainkan juga adanya konsistensi dalam putusan hakim antara putusan hakim yang satu dengan putusan hakim lainnya untuk kasus yang serupa yang telah di putuskan. ${ }^{34}$

Teori kepastian hukum menegaskan bahwa tugas hukum itu menjamin kepastian hukum dalam hubungan-hubungan pergaulan kemasyarakatan. Terjadi kepastian yang dicapai "oleh karena hukum". Dalam tugas itu tersimpul dua tugas lain yakni hukum harus menjamin keadilan maupun hukum harus tetap berguna. Akibatnya kadang-kadang yang adil terpaksa dikorbankan untuk yang berguna. Ada 2 (dua) macam pengertian "kepastian hukum" yaitu kepastian oleh karena hukum dan kepastian dalam atau dari hukum. Kepastian dalam hukum tercapai kalau hukum itu sebanyak-banyaknya hukum undang-undang dan bahwa dalam undang-undang itu tidak ada ketentuan-ketentuan yang bertentangan, undang-undang itu dibuat berdasarkan "rechtswerkelijkheid" (kenyataan hukum) dan dalam undang-undang tersebut tidak dapat

34 Peter Mahmud Marzuki, Pengantar IImu Hukum, Kencana Pranada Media Group, Jakarta, 2008, hlm 158 istilah-istilah yang dapat di tafsirkan berlainIainan. ${ }^{35}$

Menurut Satjipto Raharjo bahwa: teori kemanfaatan (kegunaan) hukum bisa dilihat sebagai perlengkapan masyarakat untuk menciptakan ketertiban dan keteraturan. Oleh karena itu ia bekerja dengan memberikan petunjuk tentang tingkah laku dan berupa norma (aturan-aturan hukum). ${ }^{36}$ Pada dasarnya peraturan hukum yang mendatangkan kemanfaatan atau kegunaan hukum ialah untuk terciptanya ketertiban dan ketentraman dalam kehidupan masyarakat, karena adanya hukum tertib (rechtsorde).

Kepastian hukum adalah jaminan bahwa hukum dijalankan, bahwa yang berhak menurut hukum dapat memperoleh haknya dan bahwa putusan dapat dilaksanakan. Kepastian hukum merupakan perlindungan yustisiabel terhadap tindakan sewenang-wenang yang berati bahwa seseorang akan dapat memperoleh sesuatu yang diharapkan dalam keadaan tertentu. Hukum bertugas menciptakan kepastian hukum karena bertujuan untuk menciptakan ketertiban dalam masyarakat.

c. Teori Tanggung Jawab.

Teori ini digunakan untuk menggambarkan bahwa utang yang dimiliki oleh debitor merupakan tanggung jawab hukum yang wajib ditunaikan atas hubungan hukum yang telah dilakukan oleh debitor.

Menurut hukum tanggung jawab adalah suatu akibat atas konsekuensi kebebasan seorang tentang perbuatannya yang berkaitan dengan etika atau moral dalam

35 M. Solly Lubis, Diktat Teori Hukum, disampaikan pada Rangkaian Sari Kuliah Semester II, Program Pasca Sarjana Ilmu Hukum, USU Medan, 2007, hlm. 43

36 Satjipto Rahardjo, IImu Hukum, Alumni, Bandung, 2001, hlm.13 
Media Komunikasi dan Informasi Hukum dan Masyarakat

melakukan suatu perbuatan. ${ }^{37}$ Menurut Titik Triwulan pertanggungjawaban harus mempunyai dasar, yaitu hal yang menyebabkan timbulnya hak hukum bagi seorang untuk menuntut orang lain sekaligus berupa hal yang melahirkan kewajiban hukum orang lain untuk memberi pertanggungjawabannya. ${ }^{38}$

\section{Menurut Abdulkadir Muhammad} bahwa teori tanggung jawab dalam perbuatan melanggar hukum (tort liability) dibagi menjadi beberapa teori, yaitu :

1) Tanggung jawab akibat perbuatan melanggar hukum yang dilakukan dengan sengaja (intertional tort liability), tergugat harus sudah melakukan perbuatan sedemikian rupa sehingga merugikan penggugat atau mengetahui bahwa apa yang dilakukan tergugat akan mengakibatkan kerugian.

2) Tanggung jawab akibat perbuatan melanggar hukum yang dilakukan karenakelalaian (negligence tort lilability), didasarkan pada konsep kesalahan (concept of fault) yang berkaitan dengan moral dan hukum yang sudah bercampur baur (interminglend).

3) Tanggung jawab mutlak akibat perbuatan melanggar hukum tanpa mempersoalkan kesalahan (stirck liability), didasarkan pada perbuatannya. ${ }^{39}$

Teori tanggung jawab hukum sebagaimana dikemukakan oleh Hans kelsen adalah suatu konsep yang berhubungan dengan konsep kewajiban hukum adalah konsep tanggung jawab hukum. Bahwa seseorang bertanggung jawab secara hukum atas suatu perbuatan tertentu atau bahwa ia

\footnotetext{
37 Soekidjo Notoatmojo, Etika dan Hukum Kesehatan, Rineka Cipta, Jakarta, 2010, hlm.87.

${ }^{38}$ Titik Triwulan dan Shinta Febrian, Perlindungan Hukum bagi Pasien, Prestasi Pustaka, Jakarta, 2010, hlm. 48

${ }^{39}$ Abdulkadir Muhammad, Hukum Perusahaan Indonesia, Citra Aditya Bakti, Bandung, 2010, hlm. 503
}

memikul tanggung jawab hukum, berarti bahwa ia bertanggung jawab atas suatu sanksi dalam hal perbuatan hukum yang bertentangan. Biasanya yakni dalam hal sanksi ditujukan kepada pelaku langsung, seseorang bertanggung jawab atas perbuatannya sendiri. ${ }^{40}$

Tanggung jawab hukum terkait dengan konsep hak dan kewajiban hukum. Konsep kewajiban biasanya dilawankan dengan konsep hak, istilah hak yang dimaksud di sini adalah hak hukum (legal right). Penggunaan linguistik telah membuat dua perbedaan hak yaitu jus in rem dan jus in personam. Jus in rem adalah hak atas suatu benda, sedang jus in personam adalah hak yang menuntut orang lain atas suatu perbuatan atau hak atas perbuatan orang lain. Pembedaan ini sesungguhnya juga bersifat ideologis berdasarkan kepentingan melindungi kepemilikan privat dalam hukum perdata. Jus in rem tidak lain adalah hak atas perbuatan orang lain untuk tidak melakukan tindakan yang mengganggu kepemilikan. ${ }^{41}$

Terkait dengan teori tanggung jawab hukum, dalam suatu peristiwa hukum utang piutang antara kreditor dan debitor menimbulkan adanya hak dan kewajiban yang harus dipenuhi oleh masing-masing pihak. Pihak kreditor berkewajiban untuk menyerahkan sejumlah dana untuk kepentingan debitor, pihak debitor memiliki kewajiban untuk mengembalikan sejumlah dana yang digunakannya kepada kreditor. Apabila debitor mengalami kemunduran usaha

\footnotetext{
${ }^{40}$ Hans Kelsen, Teori Hukum Murni dengan judul buku asli "General Theory of Law and State" alih bahasa Somardi, Rumidi Pers, Jakarta, 2001, hlm.65.

41 Jimly Asshiddiqie, dan M. Ali Safa'at, Teori Hans Kelsen Tentang Hukum, Sekretariat Jenderal \& Kepaniteraan Mahkamah Konstitusi RI, Jakarta, 2006, hlm.66-67
} 
Media Komunikasi dan Informasi Hukum dan Masyarakat

yang menyebabkannya tidak dapat mengembalikan dana yang seharusnya dikembalikan kepada kreditor maka langkah terakhir yang dapat ditempuh adalah dengan menggunakan lembaga kepailitan sebagai upaya terakhir penyelesaian utang-utangnya.

2. Konsepsi

$\begin{array}{ccc}\text { Konsep adalah kata yang } \\ \text { menyatakan } & \text { abstraksi } & \text { yang }\end{array}$
digeneralisasikan dari hal-hal yang khusus. Sedangkan pola konsep adalah serangkaian konsep yang dirangkaikan dengan dalil-dalil hipotesis dan teoritis. ${ }^{42}$ Konsep bukan merupakan gejala yang akan diteliti, akan tetapi merupakan suatu abstraksi dari gejala tersebut. Gejala itu sendiri biasanya dinamakan fakta, sedangkan konsep merupakan suatu uraian mengenai hubungan-hubungan dalam fakta tersebut. $^{43}$

Kerangka konsep dalam penelitian ini yaitu:

a. Peran adalah aspek dinamis yang berupa tindakan atau perilaku yang dilaksanakan oleh seseorang yang menempati atau memangku suatu posisi dan melaksanakan hak-hak dan kewajiban sesuaian dengan kedudukannya. Seseorang yang menjalankan peran tersebut dengan baik, dengan sendirinya akan berharap bahwa apa yang dijalankan sesuai dengan keinginan diri lingkungannya. ${ }^{44}$

b. OJK adalah lembaga yang independen dan bebas dari campur tangan pihak lain, yang mempunyai fungsi, tugas, dan

${ }^{42}$ Amiruddin dan Zainal Asikin, Pengantar Metode Penelitian Hukum, Raja Grafindo Persada, Jakarta, 2006, hlm. 2

${ }^{43}$ Soerjono Soekanto, Pengantar Penelitian Hukum, Universitas Indonesia, Jakarta, 2008t, hlm. 132

${ }^{44}$ WJS. Poerwadarminta, Kamus Umum Bahasa Indonesia. N. Balai Pustaka, Jakarta, 2008, hlm.751. wewenang, pengaturan, pengawasan, pemeriksaan dan penyidikan. ${ }^{45}$

c. Melindungi adalah menutupi supaya tidak terlihat atau tampak, menjaga, merawat, memelihara, menyelamatkan (memberi pertolongan) supaya terhindar dr mara bahaya. $^{46}$

d. Pemegang Polis adalah yang namanya dicantumkan di dalam polish sebagai pihak yang mengadakan kontrak asuransi dengan penanggung (perusahaan asuransi). ${ }^{47}$

e. Polis Asuransi kontrak tertulis antara perusahaan asuransi (penanggung) dan nasabah (tertanggung) yang berisi pengalihan risiko dan syarat-syarat berlaku (jumlah uang pertanggungan, jenis risiko yang ditanggung, jangka waktu dan lain sebagainya). ${ }^{48}$

f. Pailit adalah suatu sitaan umum dan eksekusi atas seluruh kekayaan debitor untuk kepentingan semua kreditornya. ${ }^{49}$

g. Perusahaan perasuransian adalah perusahaan asuransi,perusahaan asuransi syariah, perusahaan reasuransi, perusahaan reasuransi syariah, perusahaan pialang asuransi, perusahaan pialang reasuransi, dan perusahaan penilai kerugian asuransi. ${ }^{50}$ 
Media Komunikasi dan Informasi Hukum dan Masyarakat

\section{G. Metode Penelitian}

\section{Jenis Penelitian.}

Jenis penelitian hukum yang digunakan adalah yuridis normatif dan penelitian hukum empiris. Penelitian yuridis normatif adalah suatu penelitian yang menempatkan norma sebagai obyek penelitian, baik norma hukum dalam peraturan perundang-undangan, norma hukum yang bersumber dari suatu undang-undang ${ }^{51}$. Disebut juga penelitian hukum doktrinal yaitu penelitian hukum yang menggunakan data sekunder. Penelitian hukum normatif dikenal sebagai penelitian hukum yang bersifat kualitatif. ${ }^{52}$

\section{Sifat Penelitian}

Penelitian ini bersifat deskriptif analisis yaitu penelitian yang menggambarkan, menelaah, menjelaskan serta menganalisa peraturan perundang-undangan yang berkaitan pada tujuan penelitian ini. Tujuan dalam penelitian deskriptif adalah untuk menggambarkan secara tepat sifat-sifat individu, keadaan, gejala atau kelompok tertentu, atau untuk menentukan frekuensi atau penyebaran suatu gejala atau frekuensi adanya hubungan tertentu antara gejala dan gejala lain dalam masyarakat. ${ }^{53}$ Maksud utama analisis terhadap bahan hukum adalah mengetahui makna yang dikandung oleh istilah-istilah yang digunakan dalam aturan undang-undang secara konsepsional, sekaligus mengetahui penerapannya dalam praktik. $^{54}$

3. Sumber Data

Sumber data penelitian ini adalah :

a. Data primer.

Sumber data utama, dalam penelitian ini juga digunakan data primer sebagai data pendukung yang diperoleh dari wawancara. Wawancara dilakukan dengan pihak-pihak yang telah ditentukan sebagai informan atau narasumber dikhususkan untuk pemecahan masalah yang masih memerlukan informasi lebih lanjut dalam memastikan validitas data-data sekunder yang telah diperoleh.

b. Data sekunder

Data sekunder yang dimaksud antara lain meliputi bahan hukum primer, bahan hukum sekunder, dan bahan hukum tertier berupa norma dasar, perundangundangan, hasil penelitian ilmiah, bukubuku, dan lain-lain sebagainya. ${ }^{55}$

Sumber bahan hukum yang digunakan dalam penelitian ini berasal dari data sekunder yang diperoleh melalui :

1) Bahan Hukum Primer :

Bahan hukum primer terdiri dari asas dan kaidah hukum. Perwujudan asas dan kaidah hukum ini berupa Undang-Undang Republik Indonesia Nomor 37 Tahun 2004 Tentang Kepailitan dan Penundaan Kewajiban Pembayaran Utang, serta Undang-Undang Nomor 13 Tahun 2003 Tentang Ketenagakerjaan.

54 Johnny Ibrahim, Teori dan Metodologi Penelitian Hukum Normatif, Bayumedia Publishing, Malang, 2008, hlm. 310

55 Amiruddin dan Zainal Asikin, Pengantar Metode Penelitian Hukum, Raja Grafindo Persada, Jakarta, 2004, hlm.30 
Media Komunikasi dan Informasi Hukum dan Masyarakat

2) Bahan Hukum Sekunder terdiri atas bukubuku hukum (text book), jurnal-jurnal hukum, karya tulis hukum atau pandangan ahli hukum yang termuat dalam media masa, kamus dan ensiklopedia hukum, internet dengan menyebut nama situsnya. Di dalam penelitian ini, buku-buku hukum yang dipergunakan diantaranya buku tentang kepailitan.

3) Bahan hukum tertier yaitu bahan yang member petunjuk dan penjelasan terhadap bahan hukum primer dan bahan hukum sekunder seperti kamus umum, kamus hukum, ensiklopedia dan lain sebagainya. ${ }^{56}$

4. Teknik Pengumpulan Data

Pengumpulan data merupakan salah satu tahapan dalam proses penelitian yang sifatnya mutlak untuk dilakukan karena data merupakan sumber yang akan diteliti. Pengumpulan data difokuskan pada pokok permasalahan yang ada, sehingga dalam penelitian tidak terjadi penyimpangan dan kekaburan dalam pembahasannya. Pengumpulan data dalam penelitian ini mempergunakan data primer dan data sekunder.

Adapun teknik pengumpulan data yang dilakukan adalah dengan cara :

a. Penelitian Kepustakaan (library research) yaitu studi dokumen-dokumen yang relevan dengan penelitian ini di perpustakaan dan melakukan identifikasi data. Data yang diperoleh melalui penelitian kepustakaan tersebut selanjutnya akan dipilah-pilah guna memperoleh pasal-pasal yang berisi kaedah-kaedah hukum yang kemudian

${ }^{56}$ Nomensen Sinamo, Metode Penelitian Hukum dalam Teori dan Praktek, Bumi Intitama Sejahtera, Jakarta, 2010, hlm.16. dihubungkan dengan permasalahan yang sedang dihadapi dan disistematisasikan sehingga menghasilkan klasifikasi yang selaras dengan permasalahan penelitian ini. Selanjutnya data yang diperoleh tersebut akan dianalisis secara induktif kualitatif untuk sampai pada kesimpulan, sehingga pokok permasalahan yang ditelaah dalam penelitian ini akan dapat dijawab.

b. Penelitian lapangan (field research) yaitu melakukan penelitian lapangan dengan menganalisis putusan pengadilan yang telah mempunyai kekuatan hukum tetap.

5. Analisis Data

Analisis data adalah suatu proses mengatur, mengurutkan, mengelompokkan, memberikan kode dan mengategorikannya hingga kemudian mengorganisasikan dalam suatu bentuk pengelolaan data untuk menemukan tema dan hipotesis kerja yang diangkat menjadi teori substantif. ${ }^{57}$ Untuk menemukan teori dari data tersebut maka menggunakan metode kualitatif adalah penelitian yang mengacu pada norma hukum yang terdapat dalam peraturan perundangundangan dan putusan pengadilan serta norma-norma yang hidup dan berkembang dalam masyarakat. ${ }^{58}$

Data penelitian dianalisis secara kualitatif artinya data yang berdasarkan uraian kalimat atau data tidak dianalisis dengan menggunakan statistik atau matematika ataupun sejenisnya, yaitu apa yang dinyatakan responden secara tertulis ataupun lisan dan perilaku nyata yang diteliti dan dipelajari

57 Lexy J Moleong, Metodologi Penelitian Kualitatif, Remaja Rosdakarya, Bandung, 1993, hlm. 103

${ }^{58}$ Zainuddin Ali, Metode Penelitian Hukum, Sinar Grafika, Jakarta, 2009, hlm. 105 
Media Komunikasi dan Informasi Hukum dan Masyarakat

sebagai sesuatu yang utuh. $^{59}$ Sedangkan metode berpikir yang digunakan penulis yaitu deduktif, yakni pengerucutan dari bagian umum yang merupakan permasalahan umum kepada permasalahan yang lebih khusus. ${ }^{60}$.

\section{PEMBAHASAN}

\section{A. Kewenangan Otoritas Jasa Keuangan Dalam Kepailitan Perusahaan Asuransi}

\section{Otoritas Jasa Keuangan}

\section{a. Pengertian Otoritas Jasa Keuangan \\ Otoritas Jasa Keuangan yang} merupakan otoritas tunggal di sektor jasa keuangan di Indonesia, yang dibentuk melalui Undang-Undang Nomor 21 Tahun 2011 tentang Otoritas Jasa Keuangan (selanjutnya disebut UU OJK) mempunyai tujuan agar keseluruhan kegiatan di sektor jasa keuangan terselenggara secara teratur, adil, transparan dan akuntabel serta mampu mewujudkan sistem keuangan yang tumbuh secara berkelanjutan dan stabil dan mampu melindungi kepentingan konsumen dan masyarakat. ${ }^{61}$ Definisi secara umum yang dimaksud dengan Lembaga Keuangan adalah setiap perusahaan yang bergerak di bidang keuangan, menghimpun dana, menyalurkan dana atau kedua-duanya. ${ }^{62}$ Sesuai dengan laju pertumbuhan ekonomi dan gerak pembangunan suatu bangsa.

Lembaga keuangan tumbuh dengan berbagai alternatif jasa yang ditawarkan. ${ }^{63}$ Paling tidak ada sembilan fungsi pokok yang dapat dilayani lembaga keuangan bank dan

\footnotetext{
${ }^{59}$ Soerjono Soekanto, Op.Cit, hlm. 32

60 Ibid., hlm. 11

${ }^{61}$ Undang-Undang Repulik Indonesia, Peraturan Pemerintah Nomor 11 Tahun 2014, Penjelasan Umum

${ }^{62}$ Kasmir, Bank dan Lembaga Keuangan lainnya, Raja Grafindo Persada, Jakarta, 2011, hlm. 2.

63 Neni Sri Imaniyati, Pengantar hukum Perbankan Indonesia, Refika Aditama, Bandung, 2010, hlm. 1
}

selain bank yakni fungsi kredit, fungsi investasi, fungsi pembayaran, fungsi tabungan, fungsi pengelolaan kas, fungsi penjamin, fungsi perantara, fungsi perlindungan, dan fungsi kepercayaan. ${ }^{64}$

Pembinaan dan pengawasan terhadap lembaga keuangan bank dan selain bank dilakukan oleh Bank Indonesia dan menteri keuangan, yang sekarang menjadi kewenangan Otoritas Jasa Keuangan (selanjutnya disebut OJK) sebagai penyelenggara sistem pengaturan dan pengawasan yang terintegrasi terhadap keseluruhan kegiatan di dalam sektor jasa keuangan sesuai dengan UU OJK. ${ }^{65}$

Fungsi-fungsi ini menjadikan lembaga keuangan dapat mendorong perkembangan dan pembangunan ekonomi suatu daerah atau suatu Negara . Lembaga keuangan dapat memobilisasi dana dari masyarakat atau dari luar daerah yang kemudian disalurkan kembali kedalam perekonomian dalam bentuk kredit. ${ }^{66}$

Fungsi OJK sebagai regulator adalah penyelengaraan sistem pengaturan dan pengawasan yang terintegrasi terhadap keseluruhan kegiatan di sektor keuangan. Berdasarkan itu, keseluruhan kegiatan jasa keuangan yang dilakukan oleh lembaga lembaga keuangan tunduk pada sistem pengaturan dan pengawasan OJK, seperti sektor perbankan, pasar modal, perasuransian, dana pensiun, lembaga pembiayaan dan lembaga jasa keuangan lainnya. ${ }^{67}$

64 Juli Irmayanto dkk, Bank dan lembaga keuangan,Universitas Trisaksi, Jakarta, 2002, hlm. 12.

65 Republik Indonesia, Undang-Undang Nomor 21 Tahun 2011 tentang Otoritas Jasa Keuangan, Bab II, Pasal 5 dan Pasal 6.

66 Frianto Pandia, Elly Santi Ompusunggu, Achmad Abror, Lembaga keuangan Rineka Cipta, Jakarta, 2004, hlm. 1.

${ }^{67}$ Bismar Nasution, "OJK Sebagai Suatu Sistem Hukum Dalam Pembangunan Ekonomi",Makalah disampaikan pada Seminar tentang Keberadaan Otoritas Jasa Keuangan untuk mewujudkan perkonomian nasional 
Media Komunikasi dan Informasi Hukum dan Masyarakat

Guna mencapai tujuan sebagaimana yang diamanatkan oleh undang-undang, OJK memerlukan adanya jaminan sumber pembiayaan yang mampu mendukung efektifnya pelaksanaan tugas dan fungsi sebagai salah satu unsur menjadikan OJK sebagai lembaga yang independen dalam pengaturan dan pengawasan sektor jasa keuangan. ${ }^{68}$ Sesuai dengan Pasal 34 ayat 2 UU OJK, Angaran OJK bersumber dari Anggaran Pendapatan dan Belanja Negara dan/atau Pungutan dari pihak yang melakukan kegiatan di sektor jasa keuangan.

Ketentuan tersebut bermakna bahwa pembiayaan kegitan OJK, sewajarnya didanai secara mandiri yang pendanaanya bersumber dari pungutan kepada pihak yang melakukan kegiatan di sektor jasa keungaan, pembiayaan secara adil harus dibebankan kepada pihak yang secara langsung menerima manfaat dari efektifnya fungsi pengaturan dan pengawasan sektor jasa keuangan oleh OJK. ${ }^{69}$ Pungutan yang diwajibkan kepada industri jasa keuangan ini diyakini dapat dirasakan manfaatnya kembali oleh industri (recycling) dengan berbagai program kerja OJK yang bernilai tambah pada bidang pengaturan dan pengawasan terintegrasi, perlindungan konsumen dan good governance. Program kerja yang bernilai tambah itu diarahkan untuk meningkatkan pemahaman dan kepercayaan konsumen terhadap sektor jasa keuangan sehingga mampu menciptakan dan membangun pertumbuhan industri jasa

yang berkelanjutan dan stabil, Medan, 25 November 2014, hlm. 4.

68 Zulkarnain Sitompul, "Fungsi dan Tugas Otoritas Jasa Keuangan dalam menjaga stabilitas Sistem Keuangan," disampaikan pada Seminar tentang Keberadaan Otoritas Jasa Keuangan untuk Mewujudkan Perkonomian Nasional yang Berkelanjutan dan Stabil, Medan, 25 November 2014, hlm. 16

69 lbid., hlm. 17. keuangan yang berkelanjutan. ${ }^{70}$

Pada akhirnya yang paling penting itu pengawasannya efektif atau tidak. Karena pada prinsipnya dibentuk OJK agar supaya pengawasan itu menjadi terintegrasi dan koordinasinya menjadi lebih mudah sehingga pengawasan dan regulasinya menjadi efektif, karena sekarang kecenderungannya perbankan juga terlibat dalam berbagai transaksi misalkan di pasar modal, industri asuransi, artinya industri finansial sudah terjadi konvergensi, dimana antara lembaga keuangan itu kemudian melakukan berbagai sinergi. Bank juga memiliki berbagai anak perusahaan termasuk di dalamnya asuransi kemudian lembaga investasi, broker saham, dan lain-lain. Kebutuhannya memang adalah untuk menyatukan pengawasan, karena nanti diharapkan pengawasan ini lebih terkonsolidasi. $^{71}$ Jika Rancangan Undangundang (RUU) OJK disahkan menjadi UU, maka tugas, fungsi, dan wewenang pembinaan dan pengawasan atas sektor jasa keuangan beralih ke institusi baru yang disebut OJK. Ini berarti OJK akan mengambil alih sebagian tugas dan wewenang BI, Pasar Modal, Ditjen Lembaga Keuangan, Badan Pengawas Pasar Modal, dan institusi pemerintah lain yang memang mengawasi lembaga pengelola dana masyarakat. Tugas yang tetap dipegang $\mathrm{BI}$ adalah pengaturan kegiatan bank yang terkait dengan kewenangan otoritas moneter. ${ }^{72}$

Berdasarkan RUU OJK, secara normatif tujuan pendirian OJK adalah pertama, meningkatkan dan memelihara kepercayaan publik di bidang jasa keuangan. Kedua, menegakkan peraturan perundang- undangan

\footnotetext{
70 lbid., hlm. 19.

71 lbid., hlm.13

72 lbid., hlm.15
} 
Media Komunikasi dan Informasi Hukum dan Masyarakat

di bidang jasa keuangan. Ketiga, meningkatkan pemahaman publik mengenai bidang jasa keuangan. Keempat, melindungi kepentingan konsumen jasa keuangan. ${ }^{73} \mathrm{Di}$ samping itu tujuan pembentukan OJK ini agar $\mathrm{BI}$ fokus kepada pengelolaan moneter dan tidak perlu mengurusi pengawasan bank karena bank itu merupakan sektor dalam perekonomian. Untuk mencapai tujuan itu, OJK punya kewenangan yang luas, yaitu membuat peraturan di bidang jasa keuangan, memberi dan mencabut izin persetujuan dan lain-lain, memperoleh laporan periodik dan informasi industri jasa keuangan; mengenakan sanksi administratif, melakukan pemeriksaan, melakukan penyidikan atas pelanggaran UU, memberikan arahan atau perintah tertulis, menunjuk pengelola statuter, mewajibkan pengalihan usaha demi menjaga kepentingan nasabah, mencega kejahatandi bidang keuangan; dan mengatur pengendalian lembaga keuangan. ${ }^{74}$

\section{Pembentukan OJK ini perlu} memperhatikan berbagai macam aspek, diantaranya ialah:

a. Aspek Pembagian Tugas.

Terkait dengan regulasi, tampak jelas kaitan eratnya antara OJK dan BI sebagai otoritas moneter sekaligus bank sentral. Dengan demikian, UU OJK semestinya dibuat dengan memperhatikan sepenuhnya pasal demi pasal di dalam UU BI. Tujuannya adalah untuk memastikan terdapatnya pembagian bidang tugas secara jelas dan rinci sehingga dapat lebih koordinatif dan komunikatif dalam eksekusinya, khususnya dalam arus informasi. Dengan adanya pembagian tugas, maka akuntabilitas dan responsibilitas kedua lembaga yang membawahi sistem keuangan dan moneter di Indonesia dapat diukur. Pembagian tugas secara jelas antara $\mathrm{BI}$ dan OJK

73 Ryan Kiryanto, OJK dan Kepentingannya, Kompas, Jakarta, 14 Juni 2013, h.2. mutlak diperlukan, mengingat keterkaitan yang sangat erat antara sistem keuangan (kavling OJK) dengan sistem moneter dan pembayaran (kavling BI).

b. Aspek Koordinasi dan Sinkronisasi.

Efektivitas pelaksanaan fungsi BI sebagai otoritas moneter memerlukan dukungan sistem keuangan yang kokoh dan stabil. Sebaliknya efektivitas pelaksanaan fungsi OJK sebagai otoritas keuangan yang sehat dan stabil juga membutuhkan dukungan sistem pembayaran yang aman dan efisien. Kebijakan yang mengatur sistem keuangan berdampak pada pelaksanaan kebijakan moneter. Demikian pula sebaliknya. Mengingat bertali temalinya secara erat antara tugas dan wewenang OJK dan $\mathrm{BI}$, maka koordinasi dan komunikasi yang sinergis di antara keduanya mutlak diperlukan. Ilustrasi di atas ingin menggambarkan, betapa organisasi yang besar seperti BI dan OJK kelak memerlukan koordinasi dan sinkronisasi dalam gerak langkah dan dalam menyusun kebijakan karena implikasi yang ditimbulkan saling berpengaruh. Bercermin di masa lalu, tak jarang kebijakan $\mathrm{BI}$ yang dirumuskan secara cermat pun ternyata tak acceptable dan tidak aplicable sehingga hasilnya kurang memuaskan karena proses penyusunannya tidak memperhitungkan implikasi kebijakan yang dikeluarkan oleh institusi pemerintah lainnya.

c. Aspek Pertanggungjawaban

Aturan soal pertanggungjawaban OJK harus dipikirkan sebab tanpa ada aturan yang secara eksplisit menjelaskan kepada siapa OJK harus bertanggungjawab dan bagaimana mekanismenya, maka kejadian serupa di masa lalu di mana banyak pihak yang menyalahkan independensi BI telah "kebablasan" akan terjadi lagi pada OJK yang dibayangkan bakal menjadi lembaga super regulator

d. Aspek Sumber Daya Manusia (SDM)

Sesuai dengan bidang tugasnya, OJK memerlukan sejumlah besar SDM dengan kompetensi di bidang pengaturan dan pengawasan keuangan. Ini mengingat banyaknya bank umum, bank syariah, Bank Perkreditan Rakyat (BPR), lembaga asuransi, lembaga pembiayaan, modal ventura, anjak piutang, dana pensiun, dan asuransi yang secara keseluruhan mencapai ratusan buah, bahkan mungkin 
Media Komunikasi dan Informasi Hukum dan Masyarakat

ribuan, dengan puluhan ribu kantor layanan. Selain kompetensi, maka integritas yang tinggi juga merupakan syarat yang harus dipenuhi.

e. Aspek Teknologi Informasi (TI)

OJK dengan bidang tugas yang lebih luas, tentunya harus didukung oleh kesiapan $\mathrm{TI}$ yang lebih baik agar lembaga ini dapat bekerja dengan baik. Haruslah disadari, sistem pengawasan keuangan membutuhkan dukungan perangkat atau infrastruktur TI yang tepat guna untuk memudahkan pengiriman data dan laporan secara elektronik dari lembaga keuangan kepada otoritas keuangan.

f. Aspek Anggaran/Keuangan

Untuk menjalankan fungsi dan perannya, OJK memerlukan sumber dana yang salah satunya diperuntukkan bagi pembayaran imbalan pengelola dan tenaga kerjanya. Di negara-negara di mana OJK sudah beroperasi, umumnya sumber dana diperoleh dari iuran lembaga-lembaga keuangan di bawah pengawasan OJK, dengan catatan, sebatas untuk menutup anggaran yang telah direncanakan oleh OJK dan tanpa keuntungan. Kebutuhan dana akan menjadi lebih besar lagi jika OJK juga menjalankan peran sebagai lender of the last resort terhadap bankbank (dan mungkin juga lembaga keuangan nonbank) yang mengidap problem likuiditas yang akut sebagaimana sudah dijalankan oleh BI tempo dulu. Melihat kondisi obyektif industri keuangan nasional saat ini, khususnya perbankan nasional yang tengah recovery, rasanya tidak mungkin dan tidak tepat untuk membebankan biaya itu kepada mereka. ${ }^{75}$

Masih ada aspek-aspek lain yang juga harus diperhatikan diantaranya, aspek yuridis. Pembentukan OJK ini mengakibatkan perubahan yang berkaitan dengan tugas dan wewenang pengawasan yang sebelumnya diemban oleh institusi terkait seperti BI untuk sektor perbankan dan Bapepam-LK untuk sektor jasa keuangan lainnya di luar sektor perbankan, dengan demikian otomatis diperlukan perubahan Undang-undang yang terkait dengan sektor jasa keuangan yang lama tersebut seperti undang-undang mengenai Perbankan, Pasar Modal, Usaha Perasuransian, Dana Pensiun, Independensi OJK.

Independensi OJK ini harus disebutkan secara tegas dan jelas dalam UU yang membentuknya sehingga ia menjadi lembaga yang independen yang bebas dari campur tangan pemerintah dan/atau pihak-pihak lainnya. Cakupan objek pengawasan OJK juga harus secara tegas dan jelas disebutkan dalam Undang- undang yang membentuknya untuk menjamin kepastian hukum. ${ }^{76}$

Tugas pengawasan OJK seperti yang diatur di dalam Pasal 6 Undang-Undang OJK, yaitu : "OJK melaksanakan tugas pengaturan dan pengawasan terhadap :

a. Kegiatan jasa keuangan di sektor Perbankan.

b. Kegiatan jasa keuangan di sektor Pasar Modal.

c. Kegiatan jasa keuangan di sektor Perasuransian, Dana Pensiun, Lembaga Pembiayaan, dan Lembaga Jasa Keuangan Lainnya.

Berdasarkan ruang lingkup pengawasan ini, maka OJK adalah lembaga yang diberikan kewenangan dalam melakukan pengawasan berbagai sektor kegiatan yang berhubungan dengan jasa keuangan. Hal yang mungkin timbul di sini adalah bagaimana dengan kewenangan yang demikian luas dan mencakup berbagai bidang kegiatan jasa keuangan yang secara hukum memiliki berbagai perbedaan pendekatan, prinsip, definisi, dan karakteristik dapat disatukan dalam satu lembaga pengawas. Salah satu

\footnotetext{
${ }^{76}$ Djoni Gozali, dan Usman Rachmadi, Op. Cit,
} hlm. 107. 
Media Komunikasi dan Informasi Hukum dan Masyarakat

jawabannya adalah terletak pada bagaimana OJK dapat membangun harmonisasi yang efektif dari aspek hukum yang mengatur masing-masing sektor di jasa keuangan tersebut.

Harmonisasi hukum yang dimaksud di sini adalah suatu kondisi dimana terciptanya tatanan hukum yang saling mengisi dan berhubungan sehingga tercipta kepastian hukum bagi masyarakat dan dapat dijadikan sebagai alat penegakan hukum yang memiliki keadilan. ${ }^{77}$ Harmonisasi hukum yang ada di sektor jasa keuangan adalah suatu kerjasama yang harus dilakukan secara terus menerus dan terkoordinasiserta memiliki alat ukur yang dapat dipertanggungjawabkan. Harmonisasi di sini adalah bukan suatu harmonisasi karena kebijakan politik akan tetapi harmonisasi yang mengakar pada prinsip-prinsip utama dari industri jasa keuangan yang telah ditetapkan di dalam undang-undang.

Terlaksananya tujuan dari pembentukan lembaga keuangan dalam hal ini OJK dalam hal pengawasan bisa diperoleh secara optimal,apabila terdapat kerjasama dari pihak-pihak terkait, dalam hal ini masyarakat selaku konsumen dan pelaku investor dalam kegiatan di sektor jasa keuangan tersebut, yang dilakukan secara profesional. ${ }^{78}$

OJK diberi beberapa kewenangan yang cukup luas, termasuk kewenangan untuk menerbitkan peraturan, kebijakan dan pengarahan yang mengatur bidang-bidang yang memiliki lembaga yang berwenang masing-masing. Kewenangan yang dimaksud meliputi :

a. Mengadopsi kebijakan pengawasan.

b. Melaksanakan pengawasan, audit, pemeriksaan, penyelidikan perlindungan

\footnotetext{
${ }^{77} \mathrm{lbid}, \mathrm{hlm} .40$

${ }^{78}$ Ryan Kiryanto, Op. Cit., hlm. 71.
}

konsumen, atau tindakan lainnya sehubungan dengan institusi jasa keuangan atau institusi pendukung sektor keuangan sesuai dengan ketentuan yang berlaku.

c. Menerbitkan pengarahan tertulis kepada institusi-institusi jasa keuangan.

d. Menerapkan sanksi admiistratif kepada pihak-pihak yang terbukti melanggar hukum dan peraturan di sektor keuangan.

e. Menerbitkan dan mencabut berbagai izin dan persetujuan sebagaimana diatur dengan peraturan dan ketentuan yang berlaku. ${ }^{79}$

OJK adalah lembaga independen yang memiliki kewenangan pengawasan yang lebih luas dibandingkan cakupan pengawasan oleh Bapepam-LK. Saat ini belum terlihat secara jelas karena masih dalam masa transisi. Terbentuknya OJK adalah amanat dari Undang-Undang Nomor 3 Tahun 2004 tentang Bank Indonesia (Pasal 34) yang mengamanatkan dibentuknya lembaga pengawasan sektor jasa keuangan independen yang mencakup pengawasan, perbankan,pasar modal, industri keuangan non bank serta badan-badan lain yang menyelenggarakan pengelolaan dana masyarakat.

Pelaksanaan prinsip independen ini merupakan masalah yang krusial bagi otoritas pengawas jasa keuangan. Pentingnya independensi bagi otoritas pengawas jasa keuangan oleh karena dua hal. Pertama, hampir semua krisis keuangan yang terjadi pada tahun 1990-an diakibatkan oleh pengaruh politik. Kedua, dialihkannya kewenangan pengawasan dari bank sentral. ${ }^{80}$

Stuktur regulasi yang independen dapat diukur dari beberapa faktor sebagai berikut :

a. Independensi dari segi regulasi Regulasi di

\footnotetext{
${ }^{79} \mathrm{lbid}$. hlm. 72

${ }^{80}$ Adrian Sutedi, Segi-Segi Hukum Pasar Modal,
} Ghalia, Jakarta, 2008, hlm. 78 
bidang keuangan haruslah didesain untuk memberikan keleluasan untuk OJK dalam membentuk suatu kebijakan yang tepat. Undang-Undang yang ada haruslah memberi ruang dan fleksibilitas kepada OJK untuk dapat mendesain dan merubah kebijakan sesuai dengan kebutuhan dan perkembangan ekonomi. Apabila undangundang terlalu detail menjadi indirect interventiondimana secara tidak langsung OJK diarahkan dan dikekang untuk mengeluarkan sebuah kebijakan yang belum tentu sesuai dengan kondisi yang ada.

b. Independensi dari segi pengawasan Regulasi tidak akan menjadi efektif di dalam membentuk rezim sistem keuangan yang efisien dan stabil apabila tanpa pengawasan yang konsisten dan menyeluruh. Beberapa aspek dalam membentuk pengawasan yang independen sebagai berikut :

1) Perlindungan hukum kepada jajaran OJK dalam melaksanakan tugasnya. Jajaran OJK harus mendapat perlindungan hukum ketika mengeluarkan kebijakannya. Hal tersebut untuk menghindari adanya keragu-raguan dalam mengambil keputusan karena adanya ancaman hukum.

2) Adanya sistem dan standar yang jelas dalam peraturan OJK mengenai pengawasan dan pengenaan sanksi. Sistem dan standar yang jelas dapat mencegah penyalahgunaan kekuasaan dan menjadi alat check and balances karena keputusan yang diambil bukanlah berdasarkan kebijakan individu tetapi harus mengacu pada peraturan yang ada.

3) Sistem remunerasi yang jelas dan terjamin. Harus ada standar gaji yang cukup dan sistem jenjang karir yang berdasarkan merit. Hal ini ditujukan untuk meminimalisir potensi korupsi dan juga memastikan bahwa OJK diisi oleh orang-orang yang profesional dan kompeten dalam bidangnya.

4) Adanya sistem sanksi dan banding yang jelas. Struktur yang ada harus memberikan kejelasan dalam proses pengenaan sanksi dan upaya hukum yang dapat dilakukan serta jangka waktu dalam prosesnya.

c. Independensi dari segi institusi Independensi dari segi institusi mengacu pada status dari Otoritas Jasa Keuangan yang terpisah dari lembaga eksekutif dan legislatif. Mengingat fungsi Otoritas Jasa
Keuangan yang sangat krusial untuk menyeimbangkan keadaan perekonomian, menjadi sangat penting untuk menjaga independensi sebuah otoritas jasa keuangan dari pengaruh politik dan pemerintah. Untuk mencapai hal ini ada beberapa faktor penting yang harus diadops oleh sebuah struktur regulasi yang independen sebagai berikut :

1) Peraturan yang jelas mengenai pengangkatan dan pemberhentian dari personel senior. Kepastian mengenai proses pengangkatan dan pemberhentian diperlukan untuk memberikan jaminan kepada anggota OJK untuk dapat mengambil keputusan tanpa adanya kekhawatiran atas ancaman pemberhentian.

2) Struktur pengaturan yang jelas. Pengambil kebijakan di OJK sebaiknya bersifat kolektif dan diisi oleh para ahli dibidangnya. Hal ini untuk mencegah adanya satu individu yang terlalu dominan yang pada akhirnya mempengaruhi kebijakan yang diambil.

3) Proses pegambilan kebijakan yang transparan. Walaupun ada beberapa keputusan yang menurut sifatnya bersifat rahasia dan sensitif, proses pengambilan kebijakan yang transparan harus tetap dilakukan.

d. Independensi dari segi pembiayaan.

Independensi dari segi pembiayaan mengacu pada keterlibatan dari eksekutif dan legislatif dalam memutuskan besarnya anggaran OJK termasuk personel dan besarnya gaji. Otoritas yang mempunyai kebebasan dalam merancang anggaran dan sumber dayanya akan lebih siap untuk menghadapi tekanan politik, sehingga di dalam proses pengambilan keputusan akan dapat berjalan lebih cepat dan sesuai dengan perkembangan pasar. ${ }^{81}$

Tugas, fungsi, dan wewenang OJK tersebut diatur dalam Undang-Undang Nomor 21 Tahun 2011 tentang Otoritas Jasa Keuangan. Selain latar belakang yuridis, pembentukan Undang-Undang OJK juga dilatarbelakangi oleh kondisi serta

81 Bismar Nasution, "Struktur Regulasi Independensi Otoritas Jasa Keuangan" (Medan : Makalah disampaikan pada Seminar Hukum Peran dan Tujuan Otoritas Jasa Keuangan Ikatan Hukum Ekonomi Fakultas Hukum Universitas Sumatera Utara, Medan, 2013, hlm 11 
Media Komunikasi dan Informasi Hukum dan Masyarakat

perkembangan sistem keuangan yang semakin kompleks dinamis dan saling terkait antar masing-masing subsektor keuangan, baik dalam hal produk maupun kelembagaan dan kompleksitas transaksi dan interaksi antar lembaga jasa keuangan sebagai akibat dari konglomerasi pemilikan lembaga jasa keuangan. Keberadaan OJK juga dipandang perlu untuk menghindari conflict of interest dalam lingkup internal Bank Indonesia. Pasalnya selama ini memang ada kekhawatiran bank sentral akan terjebak dalam menjalankan tugasnya antara mencapai target moneter dan pengawasan bank. ${ }^{82}$

OJK sebagai lembaga independen, dalam kapasitas sebagai pengawas terhadap berbagai kegiatan khususnya investasi, maka dibentuk satuan tugas yang diberi nama satgas waspada investasi, dalam hal ini merupakan gabungan personil dari OJK, Kejaksaan, Kepolisian,dan pihak-pihak terkait. Apabila ada kegiatan investasi yang bermasalah tapi belum meledak, maka akan ditangani oleh OJK. Sedangkan apabila kegiatan investasi bermasalah ini sudah diketahui publik,maka akan ditangani oleh kepolisian. ${ }^{83}$ OJK dalam melaksanakan tugas dan fungsi pengawasannya telah berusaha mencegah sedini mungkin praktek investasi bermasalah pada umumnya.

\section{b. Dasar Hukum Otoritas Jasa Keuangan}

Pembentukan Otoritas Jasa Keuangan di Indonesia telah diatur dalam sebuah Undang-Undang Republik Indonesia Nomor 21 Tahun 2011 tentang Otoritas Jasa Keuangan 6/2013, hlm 16

82 Jurnal Hukum dan Pasar Modal vol V,Edisi ${ }^{83} \mathrm{lbid}$. yang diundangkan pada tanggal 22 November 2011. Dalam peraturan tersebut disebutkan bahwa definisi dari Otoritas Jasa Keuangan adalah lembaga yang independen dalam melaksanakan tugas dan wewenangnya, bebas dari campur tangan pihak lain, kecuali untuk hal-hal yang secara tegas diatur dalam UU OJK ini.

Undang-Undang No. 3 Tahun 2004 tentang Bank Indonesia ditetapkan bahwa Otoritas Jasa Keuangan akan dibentuk paling lambat tahun 2010. Namun sebelum diamandemen Undang-Undang No. 23 Tahun 1999 tentang Bank Indonesia menjadi UndangUndang No. 3 Tahun 2004 tentang Bank Indonesia bunyi ketentuannya adalah "Lembaga Pengawas Jasa Keuangan/LPJK (yang kemudian menjadi Otoritas Jasa Keuangan) paling lambat sudah harus dibentuk pada akhir Desember 2002"

Pasal 34 Undang-Undang No. 3 Tahun 2004 tentang Bank Indonesia merupakan respon dari krisis yang terjadi di Asia pada tahun 1997-1998 yang sangat berpengaruh terhadap Indonesia, khususnya pada sektor perbankan. Krisis pada tahun 1997-1998 yang melanda Indonesia mengakibatkan banyaknya bank- bank yang mengalami koleps sehingga banyak yang mempertanyakan pengawasan Bank Indonesia terhadap bank-bank. Kelemahan kelembagaan dan pengaturan yang tidak mendukung diharapkan dapat diperbaiki sehingga tercipta kerangka sistem keuangan yang lebih tangguh. Lembaga Otoritas Jasa Keuangan (OJK) ini akan mengambil alih kewenangan pengawasan perbankan yang selama ini dipegang oleh Bank Indonesia (BI). ${ }^{84}$

OJK dibentuk dengan tujuan agar 
Media Komunikasi dan Informasi Hukum dan Masyarakat

keseluruhan kegiatan jasa keuangan di dalam sektor jasa keuangan terselenggara secara teratur, adil, transparan, dan akuntabel, serta mampu mewujudkan sistem keuangan yang tumbuh secara berkelanjutan dan stabil, dan mampu melindungi kepentingan konsumen dan masyarakat. Dengan tujuan ini, OJK diharapkan dapat mendukung kepentingan sektor jasa keuangan nasional sehingga mampu meningkatkan daya saing nasional.

Selain itu, OJK harus mampu menjaga kepentingan nasional, antara lain, meliputi sumber daya manusia, pengelolaan, pengendalian, dan kepemilikan di sektor jasa keuangan, dengan tetap mempertimbangkan aspek positif globalisasi. Otoritas Jasa Keuangan dibentuk dan dilandasi dengan prinsip- prinsip tata kelola yang baik, yang meliputi independensi, akuntabilitas, pertanggungjawaban, transparansi, dan kewajaran (fairness).

\section{c. Fungsi Otoritas Jasa Keuangan.}

a. Fungsi Mengatur.

OJK melaksanakan tugas pengaturan dan pengawasan terhadap:

1) Kegiatan jasa keuangan di sektor Perbankan.

2) Kegiatan jasa keuangan di sektor Pasar Modal.

3) Kegiatan jasa keuangan di sektor Perasuransian, Dana Pensiun, Lembaga Pembiayaan, dan Lembaga Jasa Keuangan Lainnya. ${ }^{85}$

\section{Untuk melaksanakan tugas pengaturan}

dan pengawasan di sektor Perbankan sebagaimana dimaksud dalam Pasal 6 huruf a, OJK mempunyai wewenang:

2) Pengaturan dan pengawasan mengenai kelembagaan bank yang meliputi:
a) Perizinan untuk pendirian bank, pembukaan kantor bank, anggaran dasar, rencana kerja, kepemilikan, kepengurusan dan sumber daya manusia, merger, konsolidasi dan akuisisi bank, serta pencabutan izin usaha bank.

b) Kegiatan usaha bank, antara lain sumber dana, penyediaan dana, produk hibridasi, dan aktivitas di bidang jasa.

3) Pengaturan dan pengawasan mengenai kesehatan bank yang meliputi:

a) Likuiditas, rentabilitas, solvabilitas, kualitas aset, rasio kecukupan modal minimum, batas maksimum pemberian kredit, rasio pinjaman terhadap simpanan, dan pencadangan bank.

b) Laporan bank yang terkait dengan kesehatan dan kinerja bank.

c) Sistem informasi debitur.

d) Pengujian kredit (credit testing).

e) Standar akuntansi bank.

4) Pengaturan dan pengawasan mengenai aspek kehati-hatian bank, meliputi:

a) Manajemen risiko.

b) Tata kelola bank.

c) Prinsip mengenal nasabah dan anti pencucian uang.

d) Pencegahan pembiayaan terorisme dan kejahatan perbankan.

e) Pemeriksaan bank. ${ }^{86}$

Melaksanakan tugas pengaturan sebagaimana dimaksud dalam Pasal 6, OJK mempunyai wewenang: 87

1) Menetapkan peraturan pelaksanaan Undang-Undang ini;

2) Menetapkan peraturan perundangundangan di sektor jasa keuangan;

3) Menetapkan peraturan dan keputusan OJK;

4) Menetapkan peraturan mengenai pengawasan di sektor jasa keuangan;

5) Menetapkan kebijakan mengenai pelaksanaan tugas OJK;

6) Menetapkan peraturan mengenai tata cara penetapan perintah tertulis terhadap Lembaga Jasa Keuangan dan pihak tertentu;

7) Menetapkan peraturan mengenai tata cara penetapan pengelola statuter pada Lembaga Jasa Keuangan;

8) Menetapkan struktur organisasi dan infrastruktur, serta mengelola, memelihara, 
Media Komunikasi dan Informasi Hukum dan Masyarakat

dan menatausahakan kekayaan dan kewajiban;

9) Menetapkan peraturan mengenai tata cara pengenaan sanksi sesuai dengan ketentuan peraturan perundang-undangan di sektor jasa keuangan. ${ }^{88}$

\section{b. Fungsi Mengawasi.}

OJK adalah lembaga yang melaksanakan tugas pengawasan sektor jasa keuangan secara terintegrasi. Untuk beroperasi sebagai lembaga pengawas yang terintegrasi, Otoritas Jasa Keuangan perlu memastikan bahwa dalam menjalankan tugas dan fungsinya dilakukan secara terpadu. Lingkup pengawasan yang dialihkan ke OJK mulai 1 Januari 2014 adalah tugas pengaturan dan pengawasan Perbankan yang meliputi halhal berikut:

1) Terkait Khusus Pengawasan dan Pengaturan Lembaga Jasa Keuangan Bank yang meliputi :

a) Perizinan untuk pendirian bank, pembukaan kantor bank, anggaran dasar, rencana kerja, kepemilikan, kepengurusan dan sumber daya manusia, merger, konsolidasi dan akuisisi bank, serta pencabutan izin usaha bank.

b) Kegiatan usaha bank, antara lain sumber dana, penyediaan dana, produk hibridasi, dan aktivitas di bidang jasa.

c) Pengaturan dan pengawasan mengenai kesehatan bank yang meliputi:

2) Terkait Pengaturan Lembaga Jasa Keuangan (Bank dan Non-Bank) yang meliputi :

a) Menetapkan peraturan dan keputusan OJK;

b) Menetapkan peraturan mengenai pengawasan di sektor jasa keuangan;

c) Menetapkan kebijakan mengenai pelaksanaan tugas OJK

d) Menetapkan peraturan mengenai tata cara penetapan perintah tertulis terhadap Lembaga Jasa Keuangan dan pihak tertentu;

e) Menetapkan peraturan mengenai tata cara penetapan pengelola statute pada Lembaga Jasa Keuangan;

f) Menetapkan struktur organisasi dan infrastruktur, serta mengelola, memelihara, dan menatausahakan kekayaan dan kewajiban

g) Menetapkan peraturan mengenai tata cara pengenaan sanksi sesuai dengan ketentuan peraturan perundangundangan di sektor jasa keuangan.

3) Terkait Pengawasan Lembaga Jasa Keuangan (Bank dan Non-Bank) yang meliputi :

a) Menetapkan kebijakan operasional pengawasan terhadap kegiatan jasa keuangan;

b) Mengawasi pelaksanaan tugas pengawasan yang dilaksanakan oleh Kepala Eksekutif;

c) Melakukan pengawasan, pemeriksaan, penyidikan, perlindungan Konsumen, dan tindakan lain terhadap Lembaga Jasa Keuangan, pelaku, dan/atau penunjang kegiatan jasa keuangan sebagaimana dimaksud dalam peraturan perundangundangan di sektor jasa keuangan;

d) Memberikan perintah tertulis kepada Lembaga Jasa Keuangan dan/atau pihak tertentu;

e) Melakukan penunjukan pengelola statuter;

f) Menetapkan penggunaan pengelola statuter;

g) Menetapkan sanksi administratif terhadap pihak yang melakukan pelanggaran terhadap peraturan perundang-undangan di sektor jasa keuangan;

h) Memberikan dan/atau mencabut: izin usaha, izin orang perseorangan, efektifnya pernyataan pendaftaran, surat tanda terdaftar, persetujuan melakukan kegiatan usaha, pengesahan, persetujuan atau penetapan pembubaran dan penetapan lain. ${ }^{89}$

Penyidik OJK mempunyai kewenangan yang besar selain berwenang melakukan penyidikan yang tidak dipunyai oleh penyidik lain. Dalam hal penyidikan terhadap tindak pidana jasa keuangan, UUOJK mengaturnya :

(1) Selain Pejabat Penyidik Kepolisian Negara Republik Indonesia, Pejabat Pegawai Negeri Sipil tertentu yang lingkup tugas dan tanggung jawabnya yang meliputi pengawasan sektor jasa keuangan di lingkungan OJK, diberi wewenang khusus sebagai penyidik sebagaimana dimaksud dalam Kitab Undang-Undang Hukum Acara Pidana.

(2) Pegawai negeri sebagaimana dimaksud dalam Pasal 27 ayat (2) dapat diangkat menjadi Penyidik Pegawai Negeri Sipil sebagaimana dimaksud pada ayat (1). 
Media Komunikasi dan Informasi Hukum dan Masyarakat

(3) Penyidik Pegawai Negeri Sipil sebagaimana dimaksud pada ayat (1) berwenang:

(a) Menerima laporan, pemberitahuan, atau pengaduan dari seseorang tentang adanya tindak pidana di sektor jasa keuangan.

(b) Melakukan penelitian atas kebenaran laporan atau keterangan berkenaan dengan tindak pidana di sektor jasa keuangan

(c) Melakukan penelitian terhadap Setiap Orang yang diduga melakukan atau terlibat dalam tindak pidana di sektor jasa keuangan;

(d) Memanggil, memeriksa, serta meminta keterangan dan barang bukti dari setiap orang yang disangka melakukan, atau sebagai saksi dalam tindak pidana di sektor jasa keuangan;

(e) Melakukan pemeriksaan atas pembukuan, catatan, dan dokumen lain berkenaan dengan tindak pidana di sektor jasa keuangan

(f) Melakukan penggeledahan di setiap tempat tertentu yang diduga terdapat setiap barang bukti pembukuan, pencatatan, dan dokumen lain serta melakukan penyitaan terhadap barang yang dapat dijadikan bahan bukti dalam perkara tindak pidana di sektor jasa keuangan;

(g) Meminta data, dokumen, atau alat bukti lain, baik cetak maupun elektronik kepada penyelenggara jasa telekomunikasi;

(h) Dalam keadaan tertentu meminta kepada pejabat yang berwenang untuk melakukan pencegahan terhadap orang yang diduga telah melakukan tindak pidana di sektor jasa keuangan sesuai dengan ketentuan peraturan perundang-undangan;

(i) Meminta bantuan aparat penegak hukum lain;

(j) Meminta keterangan dari bank tentang keadaan keuangan pihak yang diduga melakukan atau terlibat dalam pelanggaran terhadap peraturan perundang-undangan di sektor jasa keuangan;

(k) Memblokir rekening pada bank atau lembaga keuangan lain dari pihak yang diduga melakukan atau terlibat dalam tindak pidana di sektor jasa keuangan;

(I) Meminta bantuan ahli dalam rangka pelaksanaan tugas penyidikan tindak pidana di sektor jasa keuangan; dan (m) Menyatakan saat dimulai dan dihentikannya penyidikan. ${ }^{90}$

Selain itu, OJK juga melarang PUJK menggunakan strategi pemasaran produk dan/atau layanan yang merugikan Konsumen dengan memanfaatkan kondisi Konsumen yang tidak memiliki pilihan lain dalam mengambil keputusan. Dengan demikian pelaku usaha jasa keuangan, termasuk perbankan, diwajibkan untuk memberikan memberikan perlindungan konsumen dalam hal ini adalah nasabah pengguna jasa keuangan bank atas kepercayaan yang diberikan nasabah kepada bank. ${ }^{91}$

Sebagai contoh konkrit dari bentuk pengawasan yang dilakukan oleh OJK adalah dengan mewajibkan produk finansial untuk mencantumkan cap halal dan OJK yang berlaku sejak 6 Agustus 2014. ${ }^{92}$ Tindakan tersebut dilakukan sebagai bentuk perlindungan terhadap konsumen atas ketidakjelasan informasi terkait produk finansial yang ditawarkan oleh perbankan. Sehingga kini dalam penjualan produk finansial atau berpromosi disyaratkan untuk lebih jelas, jujur, dan tidak menyesatkan konsumen. Sebagai gambaran, promosi dan layanan kartu kredit kepada konsumen, selain harus memenuhi persyaratan peraturan baru yang sesuai Undang-undang Nomor 21 Tahun 2011, juga harus menjelaskan cara menghitung bunga kepada calon nasabah. Selain itu, apabila ada PUJK yang tidak mengindahkan peraturan yang ada, pihak OJK akan memberikan teguran dan langkah terakhir

\footnotetext{
90 Pasal 49 UUOJK

91 Jonker Sihombing, Op. Cit., hlm. 117.

92 lbid.
} 
Media Komunikasi dan Informasi Hukum dan Masyarakat

merekomendasikan mencabut izin operasionalnya. ${ }^{93}$

Dengan adanya peraturan Otoritas Jasa Keuangan, surat edaran Otoritas Jasa Keuangan, tindakan nyata perlu dilakukan di lapangan agar perlindungan konsumen yang telah diatur di dalamnya tidak hanya sebatas peraturan tertulis saja. Dari uraian di atas jelas sekali peran Otoritas Jasa Keuangan dalam perlindungan produk perbankan. Sehingga diharapkan kinerja dari Otoritas Jasa Keuangan ditingkatkan agar terwujud peningkatan kesejahteraan rakyat serta kepastian mutu, jumlah, dan keamanan produk atau jasa keuangan.

\section{Kewenangan Otoritas Jasa Keuangan dalam Kepailitan Perusahaan Asuransi}

Hampir tidak ada negara yang tidak mengenal kepailitan dalam hukumnya. Kepailitan merupakan suatu proses dimana seorang debitor memiliki kesulitan keuangan untuk membayar utangnya dinyatakan pailit oleh pengadilan, dalam hal ini pengadilan niaga. $^{94}$ Dengan telah ditetapkannya suatu perusahaan dalam keadaan pailit berarti bahwa kekayaan debitor akan berada di bawah sita umum dan debitor demi hukum telah kehilangan hak untuk menguasai dan mengurus kekayaan karena dianggap tidak mampu lagi. ${ }^{95}$ Ketentuan mengenai pihakpihak yang dapat mengajukan permohonan pernyataan pailit telat diatur dalam Pasal 2 KPKPU.

Setelah lebih dari satu dasawarsa UU KPKPU berlaku, terdapat beberapa perubahan yang mengatur mengenai pihak-pihak yang

\footnotetext{
93 Ibid., hlm.120.

${ }^{94}$ Abdulkadir Muhammad, Op. Cit, hlm. 12.

95 Ibid., hlm.13
}

dapat mengajukan permohonan pernyataan pailit. Hal ini disebabkan diundangkannya UU OJK. Oleh karena itu, ketentuan pihak-pihak yang dapat mengajukan permohonan pernyataan pailit adalah sebagai berikut :

1. Debitor;

2. Satu kreditor atau lebih.

3. Kejaksaan untuk kepentingan umum.

4. Bank Indonesia apabila debitornya adalah bank.

5. Otoritas Jasa keuangan apabila debitornya adalah Perusahaan Efek, Bursa Efek, Lembaga Kliring dan Penjaminan, Lembaga Penyimpanan dan Penyelesaian, Perusahaan Asuransi, Perusahaan Reasuransi dan Dana Pensiun.

6. Menteri Keuangan apabila debitornya adalah Badan Usaha Milik Negara yang bergerak di bidang kepentingan publik. ${ }^{96}$

Asuransi menjadi salah-satu pilihan bagi masyarakat untuk meminimalisir risiko yang berkemungkinan dapat menimbulkan kerugian atas harta kekayaannya atau jiwa seseorang dengan cara mengalihkan kerugian tersebut kepada perusahaan asuransi. Dalam hal tidak terjadi peristiwa yang menimbulkan kerugian, maka pihak penanggung yaitu perusahaan asuransi berkesempatan mengumpulkan premi yang dibayar oleh beberapa pihak tertanggung. ${ }^{97}$

Meminimalisir risiko yang mungkin timbul dikemudian hari dan dapat merugikan seseorang, maka dari itu dilakukanlah pengalihan risiko itu kepada penanggung yaitu perusahaan asuransi. Perusahaan asuransi sebagai lembaga pengalihan dan pembagian risiko mempunyai kegunaan positif baik bagi masyarakat, perusahaan asuransi maupun bagi pembangunan negara. ${ }^{98}$ Perseroan Terbatas merupakan bentuk perusahaan yang dominan digunakan oleh perusahaan asuransi.

\footnotetext{
${ }^{96}$ Sri Redjeki Hartono, Op. Cit, hlm. 71

97 Ibid., hlm. 14.

${ }^{98}$ Man Suparman dan Endang, Op. Cit
} 
Media Komunikasi dan Informasi Hukum dan Masyarakat

Perusahaan asuransi dalam menjalankan usahanya menghimpun dana melalui penarikan premi dengan menjanjikan akan memberi sejumlah uang sebagai ganti rugi kepada pihak yang membayar premi apabila terjadi suatu peristiwa yang merugikan pembayar premi tersebut melalui perjanjian polis asuransi. Adanya hubungan tersebut mengakibatkan perusahaan asuransi dalam kedudukan sebagai debitor. Dalam pelaksanaan perjanjian tersebut, tidak jarang salah satu pihak tidak dapat melaksanakan perjanjian sebagaimana mestinya. Hal tersebut lazim disebut dengan wanprestasi. ${ }^{99}$

Guna melindungi hak-hak pihak yang terkena perbuatan wanprestasi dari debitor, terhadapnya diberikan upaya untuk mengajukan gugatan ke Pengadilan Negeri terhadap perusahaan asuransi tersebut. Selain mengajukan gugatan, terhadap perusahaan asuransi dapat juga diajukan permohonan pernyataan pailit ke Pengadilann Niaga yang melingkupi kedudukan hukum dari perusahaan asuransi tersebut.

Kreditor yang ingin mengajukan permohonan pernyataan pailit wajib memenuhi syarat yang ditentukan dalam Pasal 2 ayat (1) UU KPKPU yaitu:

1. Mempunyai 2 (dua) atau lebih kreditor; dan

2. Mempunyai minimal 1 (satu) utang yang telah jatuh tempo dan dapat ditagih.

Pasca diundangkannya UU OJK terjadi peralihan fungsi pengaturan dan pengawasan Perusahaan Asuransi dari Menteri Keuangan yang beralih ke OJK. Hal ini berdampak pula pada pengajuan permohonan pernyataan pailit terhadap Perusahaan Asuransi yang juga beralih ke OJK. Khusus untuk sektor

\footnotetext{
${ }^{99}$ Abdulkadir Muhammad, Op. Cit., hlm. 82.
}

perasuransian, tugas dan wewenang yang sebelumnya ada pada Menteri Keuangan dalam hal pengaturan dan pengawasan kegiatan jasa non bank, maka otomatis beralih kepada OJK. Hal ini sebaagaimana dimaksud dalam Pasal 55 ayat (1) UU OJK yang berbunyi: sejak tanggal 21 Desember 2012, fungsi, tugas, dan wewenang pengaturan dan pengawasan kegiatan jasa keuangan di sektor Pasar Modal, Perasuransian, Dana Pensiun, Lembaga Pembiayaan, dan Lembaga Jasa Keuangan Lainnya beralih dari Menteri Keuangan dan Badan Pengawas Pasar Modal dan Lembaga Keuagan ke OJK."

Berdasarkan prosedur di atas, dapat diketahui bahwa terdapat beberapa mekanisme dalam pengajuan permohonan pernyataan pailit terhadap perusahaan asuransi, yaitu:

1. Kreditor dari perusahaan asuransi tersebut menyampaikan permohonan kepada OJK untuk kemudian OJK melakukan kajian apakah dimungkinkan diajukannya pengajuan permohonan pernyataan pailit tersebut terhadap perusahaan asuransi yang bersangkutan.

2. OJK melalui Dewan Komisioner OJK dapat langsung mengajukan permohonan pernyataan pailit terhadap perusahaan asuransi yang bersangkutan bilamana terdapat pertimbangan-pertimbangan mengenai stabilitas dan kondisi keuangan dari perusahaan asuransi tersebut. ${ }^{100}$

B. Perlindungan Hukum Terhadap Nasabah Yang Dirugikan Akibat Pernyataan Pailit Perusahaan Asuransi

\section{Perlindungan Terhadap Konsumen Pemegang Polis Asuransi}

Sudah sejak lama konsep asuransi hadir dalam kehidupan sosial ekonomi manusia. Perannya dalam memroteksi risiko untuk memberikan rasa aman si tertanggung membuat asuransi menjadi kebutuhan dalam

\footnotetext{
${ }^{100}$ Adrian Sutedi, Op. Cit., hlm. 112.
} 
Media Komunikasi dan Informasi Hukum dan Masyarakat

tatanan kehidupan manusia. Asuransi sebagai lembaga pengalihan dan pembagian risiko mempunyai kegunaan positif baik bagi masyarakat,perusahaan maupun bagi pembangunan negara. Bagi masyarakat, seseorang yang menutup perjanjian asuransi akan merasa tentram sebab mendapat perlindungan dari kemungkinan tertimpa suatu kerugian. Bagi perusahaan, suatu perusahaan yang mengalihkan risikonya melalui perjanjian asuransi akan dapat meningkatkan usahanya dan berani menggalang tujuan yang lebih besar. Bagi pembangunan negara, premi-premi yang terkumpul dalam suatu perusahaan asuransi dapat diusahakan dan digunakan sebagai dana untuk usaha pembangunan. Hasilnya akan dapat dinikmati oleh masyarakat. ${ }^{101}$

Polis dalam perjanjian asuransi dibuat oleh penanggung yang kemudian diberikan kepada tertanggung. Pembuatan polis oleh penanggung sesuai dengan fungsi polis sebagai bukti tertulis bagi kepentingan tertanggung. Keberadaan polis tidak mutlak tapi penting apabila dikaitkan dengan fungsinya. Tidak adanya polis bukan berarti perjanjian asuransi tidak sah, tapi bisa dituntut pembatalan, karena polis bukan merupakan syarat dalam perjanjian asuransi, tetapi keberadaaannya diwajibkan. ${ }^{102}$

Fungsi polis dalam perjanjian asuransi adalah:

1. Sebagai dasar pelaksanaan perjanjian.

2. Sebagai alat bukti tertulis.

3. Sebagai dasar tuntutan apabila terjadi sengketa.

\footnotetext{
${ }^{101}$ Man Suparman Sastrawidjaja, Op. Cit., hlm. 1 102 Ibid., hlm. 84.
}

4. Sebagai dasar penghitungan ganti rugi. ${ }^{103}$

Fungsi polis bagi penanggung selaku pihak yang berkewajiban menyerahkan polis kepada tertanggung adalah sebagai bukti tertulis atas jaminan kepada tertanggung untuk membayar ganti rugi atau klaim yang diderita oleh tertanggung, sebagai bukti otentik untuk menolak tuntutan ganti rugi atau klaim yang diajukan tertanggung atau ahli waris apabila klaim yang diajukan tidak sesuai dengan syarat yang tercantum dalam polis.

Fungsi polis bagi tertanggung tentunya merupakan kewajiban bagi penanggung yang harus dipenuhi terhadap tertanggung, yaitu:

1. Sebagai bukti tertulis atas jaminan penanggung untuk mengganti kerugian atau klaim.

2. Sebagai bukti otentik untuk menuntut penanggung apabila lalai atau tidak memenuhi jaminannya. ${ }^{104}$

Terkait dengan kewajiban penanggung terhadap polis, maka penanggung wajib menjamin atas kerugian yang diderita tertanggung atas peristiwa tidak pasti yang menimpa tertanggung, membayar klaim kepada tertanggung atau ahli warisnya, dan wajib membuat dan menandatangani polis serta segera meyerahkannya kepada tertanggung.

Asuransi tidak hanya dapat diadakan untuk kepentingan sendiri, tetapi juga untuk kepentingan pihak ketiga, baik berdasarkan kuasa umum atau kuasa khusus, bahkan tanpa pengetahuan pihak ketiga yang berkepentingan.Apabila asuransi tersebut diadakan untuk kepentingan pihak ketiga, maka menurut ketentuan Pasal 265 KUHD, hal itu ditegaskan dalam polis apakah terjadi hlm.27.

103 Man Suparman Sastrawidjaja, Op. Cit., 104 lbid, hlm. 29. 
Media Komunikasi dan Informasi Hukum dan Masyarakat

berdasarkan pemberian kuasa atau tanpa pengetahuan pihak ketiga yang berkepentingan. Hal ini dalam praktik di lapangan ditemukan oleh penulis bahwa seseorang dapat mengasuransikan orang lain contohnya keponakannya karena orang tersebut masih terdapat hubungan keluarga, misalnya seorang tante yang mengasuransikan keponakannya karena masih ada hubungan keluarga, walaupun bukan orang tua langsung keponakannya tersebut, penerima manfaat selain orang tua dari tertanggung apabila masih hidup, dapat juga tantenya tersebut sebagai pengganti orang tua apabila orang tua dari ponakannya tersebut telah meninggal dunia. ${ }^{105}$

Perjanjian asuransi yang telah memenuhi syarat umum ataupun khusus dalam arti sah menurut hukum dan tidak terkandung suatu hal yang menyebabkan batalnya perjanjian tidaklah selalu diakhiri dengan pemenuhan kewajiban pembayaran ganti rugi atau klaim oleh penanggung. Setiap peristiwa tidak pasti yang timbul dalam perjanjian asuransi adalah merupakan kewajiban penanggung untuk membayar sejumlah uang yang disebut ganti rugi (verzekerde som) kepada tertanggung, dengan syarat peristiwa tidak pasti yang terjadi tersebut adalah diakibatkan oleh peristiwa tidak pasti (onzeker voorval) yang telah disepakati dan terbukti bahwa tertanggung benar-benar berkepentingan atas kejadian yang terjadi tersebut. ${ }^{106}$

Kemudian polis dapat juga diartikan surat perjanjian asuransi jiwa yang menguraikan hal-hal yang menjadi dasar dan syarat-syarat asuransi, ditandatangani oleh

\footnotetext{
105 A. Hasyimi Ali, Bidang Usaha Asuransi, Bumi Aksara, Jakarta, 2003, hlm. 101.
}

106 Ibid., hlm. 103. penanggung dan pemegang polis. ${ }^{107}$ Dari pengertian di atas bahwa polis asuransi merupakan salah satu dari alat bukti telah terjadi perjanjian asuransi. Pada dasarnya pengertian polis asuransi jiwa sama dengan pengertian polis pada umumnya.

Perbedaan polis asuransi jiwa dengan polis asuransi pada umumnya hanya dari isi polis, dimana isi polis asuransi jiwa diatur dalam Pasal 304 KUHDagang dan isi polis pada umumnya diatur dalam Pasal 256 KUHDagang. ${ }^{108}$ Menurut Pasal 304 KUHDagang, polis asuransi jiwa harus memuat hal-hal sebagai berikut :

1. Hari ditutupnya pertanggungan

2. Nama si tertanggung

3. Nama orang yang jiwanya dipertanggungkan

4. Saat mulai dan berakhirnya bahaya bagi si penanggung

5. Jumlah uang untuk mana diadakan pertanggungan

6. Premi pertanggungan tersebut

Polis asuransi jiwa diatur sendiri dalam Pasal 304 KUHDagang, namun dapat kita lihat Pasal 304 KUHDagang mengenai isi polis asuransi jiwa tidak baku, karena masingmasing perusahaan asuransi jiwa mempunyai isi polis tersendiri yang sebenarnya tidak bertentangan dengan bentuk baku Pasal 304 KUHDagang.

Asuransi adalah lembaga kepercayaan dimana kemauan masyarakat untuk meyimpan dananya pada asuransi semata-mata dilandasi oleh kepercayaan bahwa uangnya akan dapat diperoleh kembali pada waktunya dan disertai imbalan berupa bunga. Pengalaman menunjukkan, baik di Indonesia maupun 
Media Komunikasi dan Informasi Hukum dan Masyarakat

negara-negara lain bahwa ada beberapa asuransi yang mengalami kesulitan dan terpaksa habis ditutup sehingga merugikan masyarakat, karena sebagian atau seluruh dananya tidak dapat diperoleh kembali, kenyataan demikian dapat menimbulkan, pertanyaan, bagaimana cara memberikan perlindungan kepada masyarakat penyimpan dana. Bahwa berdasarkan Peraturan Asuransi Indonesia hukum memberikan tempat nasabah untuk melindungi dirinya dengan cara:

1. Perlindungan secara implisit (Implicit deposit protection);

2. Perlindungan secara Eksplisit (Explicit
deposit protection). ${ }^{109}$

Apabila diperhatikan Undang-Undang Nomor 40 Tahun 2014 Tentang Perasuransian, bahwa perlindungan hukum terhadap pemegang polis hanyalah dilakukan secara implisit akan tetapi demi untuk kelangsungan asuransi sebagai suatu lembaga khususnya dan sistim asuransi secara umumnya perlindungan itu haruslah menjadi satu kesatuan yang utuh. Asuransi Indonesia mempunyai wewenang pembinaan dan pengawasan dalam rangka menjaga kelangsungan usaha asuransi.

Naik turunnya pemegang polis bergantung kepada naik turunnya penambahan modal yang dipertanggungkan (pembeli asuransi baru). Dengan demikian, penambahan cadangan (additional reserve) dipengaruhi oleh penambahan modal yang ditanggung. ${ }^{110}$ Pada asuransi jiwa untuk mengetahui besarnya risiko, banyak digunakan rumus-rumus matematika/statistik, yaitu teori yang disebut teori probabilitas (probability

\footnotetext{
${ }^{109}$ Emmy Panggaribuan Simanjuntak, Hukum Pertanggungan, Hukum Dagang Fakultas Hukum UGM, Yogyakarta, 2005, hlm. 44.

${ }_{110} \mathrm{lbid}, \mathrm{hlm} .45$.
}

theory). Dalam asuransi jiwa risiko ialah risiko kematian. Jadi faktor risiko mengandung unsur uncertanity (ketidakpastian atau ketidaktentuan). Besarnya degree of risk (tingkat risiko) tergantung dari besar kecilnya penyimpangan (deviasi) antara yang diperkirakan dengan kejadian sesungguhnya. Makin bertambah umur seseorang makin tinggi tingkat resiko, demikian pula sebaliknya. ${ }^{111}$

Lembaga perasuransian, sama halnya dengan lembaga perbankan, akan dipercaya apabila dapat memberikan jaminan kepercayaan kepada masyarakat. Perusahaan asuransi harus benar-benar dapat memberikan jaminan bahwa dana yang dikumpulkan akan dikembalikan di kemudian hari sesuai dengan hak nasabah. Masyarakat harus dapat diyakinkan bahwa perusahaan asuransi akan dapat memenuhi kewajibannya untuk membayar ganti rugi atas kerugian yang diderita oleh masyarakat tertanggung.

Asuransi adalah perjanjian ganti rugi antara tertanggung dan penanggung yang aktanya disebut polis asuransi. Kontrak asuransi sangat spesifik karena hanya ditandatangani oleh penanggung (perusahaan asuransi), tetapi mengikat pihak tertanggung. Isi perjanjian umumnya disusun oleh perusahaan asuransi menjadi sesuatu yang baku atau standar. Isi kontrak asuransi di samping memuat bahasa-bahasa hukum, juga sangat teknis dan spesifik, di mana pada umumnya sangat sulit untuk memahami isi polis asuransi. Jangankan pihak tertanggung, banyak pelaku dalam perusahaan perasuransian juga kurang memahami isi kontrak. Dalam bisnis asuransi, ada

Beberapa prinsip asuransi yang harus diterapkan baik oleh perusahaan asuransi

\footnotetext{
${ }^{111}$ A.Junaedi Ganie, Op. Cit., hlm. 31
} 
Media Komunikasi dan Informasi Hukum dan Masyarakat

maupun oleh masyarakat tertanggung. Setidaknya prinsip dimaksud antara lain adalah prinsip insurable interest, prinsip utmost good faith, prinsip indemnity, prinsip proximate cause, dan prinsip kontribusi dan subrogasi. ${ }^{112}$ Definisi dari prinsip utmost good faith menyebutkan bahwa si tertanggung harus memberitahukan semua fakta material dengan benar, lengkap, serta sukarela atas obyek pertanggungan, baik diminta maupun tidak diminta. Sebaliknya, perusahaan asuransi pun dituntut harus menunjukkan itikad baiknya kepada si tertanggung. Sangat sering terjadi kesalahpahaman atas penerapan prinsip ini dalam bisnis asuransi. utmost good faith seolah-olah hanya menjadi kewajiban si tertanggung, di mana si penanggung tidak perlu menunjukkan itikad baiknya kepada penanggung.

Banyak penanggung mengklaim bahwa tertanggung tidak melaksanakan itikad baik (breach of utmost good faith) sehingga klaim asuransi yang diajukan ditolak oleh perusahaan asuransi. ${ }^{113}$ Dalam banyak kasus, sering sekali niat baik tertanggung untuk melakukan sesuatu berkaitan dengan klaim asuransi menjadi bumerang karena ternyata tindakan itu melanggar ketentuan kontrak. Di sisi lain si tertanggung tidak mengetahui bahwa niat baik itu ternyata menjadi tidak baik, yang pada akhirnya menjadi area timbulnya konflik dari tuntutan ganti rugi. Adalah menjadi kewajiban si penanggung untuk menjelaskan semua hal yang berkaitan dengan kontrak asuransi, termasuk sebelum dimulai kontrak.

Penanggung yang tidak menjelaskan hak dan kewajiban si tertanggung, maka penanggung telah melanggar prinsip utmost

\footnotetext{
112 lbid, hlm. 67.

113 Ibid.
}

good faith. Karena itu, ia dapat dituntut dan harus bertanggung jawab atas ganti rugi yang diderita tertanggung. Dewasa ini perjanjian atau kontrak antara penanggung dan tertanggung hampir selalu menggunakan perjanjian atau kontrak yang berbentuk baku (polis). Penggunaan perjanjian baku ini dilakukan agar transaksi-transaksi jasa dapat dilakukan secara efisien dan praktis tanpa adanya hambatan sebagai akibat terjadinya "tawar menawar" sebelum menutup suatu perjanjian. Dalam perjanjian baku, klausulaklausula dalam perjanjian telah ditetapkan secara sepihak oleh penanggung sehingga klausula-klausula tersebut cenderung lebih mengutamakan hak-hak penanggung dibandingkan hak-hak tertanggung dan kewajiban-kewajiban penanggung.

\section{Perlindungan Hukum Terhadap Pemegang Polis Asuransi akibat Perusahaan Asuransi Dinyatakan Pailit}

Asuransi atau pertanggungan timbul karena kebutuhan manusia. Manusia selalu dihadapkan kepada sesuatu yang tidak pasti, yang mungkin menguntungkan, tetapi memungkin pula sebaliknya. ${ }^{114}$ Menurut ketentuan Pasal 255 Kitab Undang-Undang Hukum Dagang, perjanjian asuransi harus dibuat secara tertulis dalam bentuk akta yang disebut polis. ${ }^{115}$

Perusahaan asuransi tidak selamanya berjalan dengan baik, seperti penurunan tingkat perekonomian terhadap perusahaan sehingga menyebabkan perusahaan tersebut terkendala, sehingga tidak dapat melanjutkan usaha tersebut sehingga dia harus dipailitkan.

\footnotetext{
114 A. Junaedy Ganie, Hukum Asuransi Indonesia, Sinar Grafika, Jakarta, 2010, hlm. 1.

${ }^{115}$ Abdulkadir Muhammad, Op. Cit., hlm. 59.
} 
Media Komunikasi dan Informasi Hukum dan Masyarakat

Salah satu risiko dalam perasuransian adalah kemungkinan terjadinya pailit atas perusahaan asuransi. Kepailitan merupakan hal yang sangat ditakuti bagi perusahaan asuransi maupun pemegang polis asuransi tersebut. ${ }^{116}$

Perlindungan hukum bagi pemegang Polis asuransi penting sekali oleh karena, polis itu merupakan satu-satunya alat bukti tertulis untuk membuktikan bahwa asuransi telah terjadi. Polis asuransi sebagai bukti terjadinya perjanjian asuransi mengikat melalui perjanjian asuransi yang dibuktikan dengan Polis asuransi telah terjadi pemindahan resiko misalnya asuransi jiwa atau asuransi kerugian kepada perusahaan asuransi. Abdul Kadir Muhammad menjelaskan, melalui perjanjian asuransi resiko kemungkinan terjadi peristiwa yang menimbulkan kerugian yang mengancam kepentingan tertanggung itu dialihkan kepada perusahaan asuransi kerugian selaku penanggung. ${ }^{117}$

Klaim yang diajukan oleh pemegang polis asuransi terhadap perusahaan asuransi tidak jarang berbelit-belit, dan ditolak dengan berbagai alasan sehingga perlindungan bagi kepentingan pemegang Polis asuransi menjadi bagian penting dan berkaitan dengan fungsi OJK dalam menjalankan fungsi pengaturan dan pengawasan serta perlindungan konsumen jasa asuransi. ${ }^{118}$

Penerapan unitlink oleh perusahaan asuransi, seringkali tidak secara terbuka dan menempatkan posisi pemegang Polis asuransi pada posisi lemah. Biaya-biaya yang harus dibayar, dan resiko-resiko investasi di unitlink harus diketahui nasabah dengan membaca

116 Djoko Prakoso dan I Ketut Murtika, Hukum Asuransi Indonesia, Bina Aksara, Jakarta, 2009, hlm. 92.

${ }^{117}$ Abdulkadir Muhammad, Op. Cit., hlm. 166.

118 lbid., hlm. 167. proposal secara teliti. ${ }^{119}$ Adalah bergantung pada pemegang polis asuransi apakah mengikuti program unitlink atau tidak, mengingat bujukan para agen asuransi sangat kuat yang kadangkala tanpa memperhitungkan kepentingan dan perlindungan hukum bagi pemegang Polis Asuransi. ${ }^{120}$

\section{Perjanjian asuransi sebagai bukti} adanya hubungan hukum antara perusahaan asuransi dengan pemegang polis, dapat saja ketika penandatanganan perjanjian asuransi, telah terjadi klausul-klausul baku sebagai bentuk perjanjian baku yang menempatkan pemegang polis pada posisi lemah dan tidak seimbang. Munir Fuady menjelaskan beberapa faktor penyebab sehingga seringkali kontrak baku menjadi berat sebelah, adalah sebagai berikut :

1. Kurang adanya atau bahkan tidak adanya kesempatan bagi salah satu pihak untuk melakukan tawar-menawar, sehingga pihak yang kepadanya disodorkan kontrak tidak banya kesempatan untuk mengetahui isi kontrak tersebut, apalagi ada kontrak yang ditulis dengan huruf-huruf yang sangat kecil.

2. Karena penyusunan kontrak yang sepihak, maka pihak penyedia dokumen biasanya memiliki cukup banyak, waktu untuk memikirkan mengenai klausula-klausula dalam dokumen tersebut, bahkan mungkin saja sudah berkonsultasi dengan para ahli, sedangkan pihak yang kepadanya disodorkan dokumen tidak banyak kesempatan dan seringkali tidak familiar dengan klausula-klausula tersebut.

3. Pihak yang kepadanya disodorkan kontrak baku menempati kedudukan yang sangat tertekan, sehingga hanya dapat bersifat "take it or leave it". ${ }^{121}$ 
Media Komunikasi dan Informasi Hukum dan Masyarakat

III. KESIMPULAN DAN SARAN

\section{A. Kesimpulan}

Berdasarkan

pembahasan-

pembahasan sesuai dengan rumusan masalah, maka diperoleh kesimpulan :

1. Kewenangan Otoritas Jasa Keuangan dalam kepailitan perusahaan asuransi didasarkan pada UU KPKPU dan UU OJK dengan pengaturan pelaksananya serta kedudukan OJK sebagai pihak yang mengajukan permohonan pernyataan pailit melalui Dewan Komisioner OJK yang diwakili oleh pegawai internal OJK berdasarkan Surat Kuasa Khusus dan sebagai wakil dari para kreditor dalam perkara kepailitan yang bersangkutan. Pengajuan permohonan pernyataan pailit oleh OJK ditujukan untuk melindungi kepentingan nasabah pemegang polis asuransi dan juga hak-hak keperdataan nasabah pemegang polis asuransi.

2. Perlindungan hukum terhadap nasabah yang dirugikan akibat pernyataan pailit perusahaan asuransi mendapat perlindungan hukum dalam berbagai peraturan perundang-undangan seperti dalam Undang-Undang No. 21 Tahun 2011 tentang Otoritas Jasa Keuangan, UndangUndang No. 40 Tahun 2014 tentang Perasuransian, serta dalam Peraturan Otoritas Jasa Keuangan No. 1/POJK.07/2013 tentang Perlindungan Konsumen Sektor Jasa Keuangan. Perlindungan yang diberikan kepada pemegang polis asuransi dalam kasus kepailitan yaitu dijaminnya kedudukan pemegang polis dalam hal terjadi kepailitan terhadap perusahaan asuransi yang telah diatur secara tegas di dalam Pasal 52 ayat (1) dan (2) UU Peransuransian yaitu, pemegang polis berkedudukan sebagai kreditur yang diutamakan (preferen) dalam hal memperoleh pengembalian premi dari harta kekayaan perusahaan asuransi yang pailit dan terlebih lagi bagi para pemegang polis yang berhak atas manfaat asuransi dijamin dengan polis asuransi untuk memperoleh pembayaran klaim.

\section{A. Saran}

Bahagian akhir tesis ini, maka disarankan sebagai berikut :

1. Besar harapan masyarakat khususnya nasabah Bumi Asih Jaya kepada OJK sebagai lembaga pengawas lebih memperhatikan perlindungan terhadap nasabah asuransi, dan OJK sebagai lembaga perlindungan konsumen yang berwenang untuk terus mengawasi sampai dimana proses likuidasi perusahaan Bumi Asih Jaya agar hak-hak para pemegang polis bisa terlindungi dan mendapatkan pengembalian klaim sesuai dengan perjanjian asuransi.

2. Perlindungan terhadap pemegang polis untuk mendapatkan hak-haknya pada kepailitan perusahaan asuransi ini, hendaknya kurator sebagai orang yang berwenang mengurus semua harta kekayaan perusahaan asuransi harus memperhatikan isi perjanjian dalam polis asuransi supaya pelaksanaan kewajiban perusahaan asuransi kepada pemegang polis bisa terlaksana dengan baik. 
Media Komunikasi dan Informasi Hukum dan Masyarakat

\section{DAFTAR PUSTAKA}

\section{A. Buku}

Ali, A. Hasyimi, Bidang Usaha Asuransi, Bumi Aksara, Jakarta, 2003.

Ali, Zainuddin, Metode Penelitian Hukum, Sinar Grafika, Jakarta, 2009.

Amriani, Nurnaningsih, Mediasi. Alternatif Penyelesaian Sengketa Perdata di Pengadilan, RajaGrafindo Persada, Cetakan Pertama, Jakarta, 2011,

Amiruddin dan Zainal Asikin, Pengantar Metode Penelitian Hukum, Raja Grafindo Persada, Jakarta, 2006.

Arifin, Mohamad, Teori Dan Filsafat Hukum. RajaGrafindo Persada, Jakarta, 2003.

Asshiddiqie, Jimly dan M. Ali Safa'at, Teori Hans Kelsen Tentang Hukum, Sekretariat Jenderal \& Kepaniteraan Mahkamah Konstitusi RI, Jakarta, 2006.

Ashofa, Burham, Metode Penelitian Hukum, Rineka Cipta, Jakarta, 2007.

Apeldoorn, Van, Pengantar IImu Hukum, Pradnya Paramita, Jakarta, 1999.

Bruggink, J.J. H. Refleksi Tentang Hukum, Citra Aditya Bakti, Bandung, 1999

Djohansah, J. Pengadilan Niaga Di Dalam Penyelesaian Utang Melalui Pailit, Alumni, Bandung, 2001

Friedman, Lawrence. M. American Law an Introduction, Terjemahan Wisma Bhakti, PT. Tata Nusa, Jakarta, 2001

Fuady, Munir, Hukum Pailit Dalam Teori dan Praktek, Citra Aditya Bakti, Bandung, 2002.

---------; Hukum Kontrak (Dari Sudut Pandang Hukum Bisnis), Citra Aditya Bakti, Bandung, 2003

Ganie, A. Junaedy, Hukum Asuransi Indonesia, Sinar Grafika, Jakarta, 2011

Gautama, Sudargo, Komentar atas Peraturan Baru Untuk Indonesia, Citra Aditya Bakti, Bandung, 1998.
Gozali, Djoni dan Usman Rachmadi, Hukum Perbankan, Sinar Grafika, Jakarta, 2012.

Gunawan, Johanes, Tanggung Jawab Pelaku Usaha menurut Undang-Undang No. 8. Tahun 1999 tentang Perlindungan Konsumen, Alumni, Bandung, 2000.

Halim, Swady, Permasalahan Umum Nasabah Asuransi, Lembaga Studi Pers dan Informasi, Semarang, 2010

Hamzah, Andi, Kamus Hukum, Ghalia Indonesia, 2005

Hartanto, Andy, Hukum Jaminan dan Kepailitan, Hak Kreditor Separatis dalam Pembagian Hasil Penjualan Benda Jaminan Debitor Pailit, LaksBang Justitia, Surabaya, 2015.

Hartono, Sri Rezeki, Hukum Asuransi dan Perusahaan Asuransi, Sinar Grafika, Jakarta, 2005,

Ibrahim, Johnny, Teori dan Metodologi Penelitian Hukum Normatif, Bayumedia Publishing, Malang, 2008.

Imaniyati, Neni Sri, Pengantar hukum Perbankan Indonesia, Refika Aditama, Bandung, 2010.

Irmayanto, Juli dkk, Bank dan lembaga keuangan,Universitas Trisaksi, Jakarta, 2002

Jono, Hukum Kepailitan, Sinar Grafika, Jakarta, 2008.

Kasmir, Bank dan Lembaga Keuangan lainnya, Raja Grafindo Persada, Jakarta, 2011.

Khakim, Abdul, Dasar-Dasar Hukum Kentenagakerjaan Indonesia, Citra Aditya Bhakti Bandung, 2009.

Kelsen, Hans, Teori Hukum Murni dengan judul buku asli "General Theory of Law and State" alih bahasa Somardi, Rumidi Pers, Jakarta, 2001

Kontjaraningrat, Metode-Metode Penelitian Masyarakat, Gramedia, Jakarta, 1997.

Kristiyanti, Celina Tri Siwi, Hukum Perlindungan Konsumen, Sinar Grafika, Jakarta, 2009 
Media Komunikasi dan Informasi Hukum dan Masyarakat

Lontoh, Rudy A. (ed), Menyelesaikan Utang Piutang Melalui Pailit atau Penundaan Kewajiban Pembayaran Utang, Alumni, Bandung, 2001

Lubis, Ida Hanifah, Pengantar Hukum Ketenagakerjaan di Indonesia, Ratu Jaya, Medan, 2009.

Lubis, M. Solly, Filsafat IImu dan Penelitian, Mandar Maju, Bandung, 1994.

; Diktat Teori Hukum, disampaikan pada Rangkaian Sari Kuliah Semester II, Program Pasca Sarjana IImu Hukum, USU Medan, 2007

Marzuki, Peter Mahmud, Pengantar IImu Hukum, Kencana Pranada Media Group, Jakarta, 2008.

Miru, Ahmadi, Hukum Kontrak dan Perancangan Kontrak, RajaGrafindo Persada, Jakarta, 2014

Mochtar, Zainal Arifin dan Iwan Satriawan, Jurnal Konstitusi, Volume 6, Nomor 3, Jakarta, September 2012

Moleong, Lexy J, Metodologi Penelitian Kualitatif, Remaja Rosdakarya, Bandung, 1993.

Nasution, Mulya, Asuransi Dan Usaha Perasuransian Di Indonesia, Alfabeta, Bandung, 2013

Nating, Imran, Peranan dan Tanggung Jawab Kurator dalam Pengurusan dan Pemberesan Harta Pailit, Edisi Revisi 2, Raja Grafindo, Jakarta, 2009.

Nitisusastro, Mulyadi, Asuransi dan Usaha Perasuransian di Indonesia Alfabeta, Bandung, 2013

Muhammad, Abdulkadir, Hukum Perusahaan Indonesia, Citra Aditya Bakti, Bandung, 2010.

--;Hukum Asuransi Indonesia, Citra Aditya Bakti, Bandung, 2015.

Notoatmojo, Soekidjo, Etika dan Hukum Kesehatan, Rineka Cipta, Jakarta, 2010

Pandia, Frianto Elly Santi Ompusunggu, Achmad Abror, Lembaga keuangan Rineka Cipta, Jakarta, 2004.
Poerwadarminta, WJS. Kamus Umum Bahasa Indonesia, PN. Balai Pustaka, Jakarta, 2007.

Prakoso, Djoko dan I Ketut Murtika, Hukum Asuransi Indonesia, Bina Aksara, Jakarta, 2009

Rahardjo, Satjipto, Ilmu Hukum, Alumni, Bandung, 1991

-; Sosiologi Hukum : Perkembangan, Metode dan Pilihan Hukum, Universitas Muhamadyah, Surakarta, 2004

Rasjidi, Lili dan Ira Tania Rasjidi, Pengantar Filsafat Hukum, Mandar Maju, Bandung, 2002.

Salim, A.Abbas, Asuransi dan Manajemen Resiko. Raja Grafindo Persada. Jakarta, 2008

Saliman, Abdul R. dkk, Hukum Bisnis Untuk Perusahaan; Teori dan Contoh Kasus, Renada Media Grup, Jakarta, 2005

Sastrawidjaja, Man HS, Hukum Kepailitan dan Penundaan Kewajiban Pembayaran Utang, Alumni, Bandung, 2006.

Sedarmayanti \& Syarifudin Hidayat, Metodologi Penelitian, Mandar Maju, Bandung, 2002.

Sihombing, Jonker, Otoritas Jasa Keuangan : Konsep, Regulasi dan Implementasi, Ref Publisher, Jakarta, 2012.

Simanjuntak, Emmy Pangaribuan, Hukum Pertanggungan, Hukum Dagang Fakultas Hukum UGM, Yogyakarta, 2005

Sinamo, Nomensen, Metode Penelitian Hukum dalam Teori dan Praktek, Bumi Intitama Sejahtera, Jakarta, 2010

Soekanto, Soerjono, dan Sri Mamudji, Penelitian Hukum Normatif, Rajawali Pers,Jakarta, 1995

Soekanto, Soerjono, Pengantar Penelitian Hukum, Universitas Indonesia, Jakarta, 2008 
Media Komunikasi dan Informasi Hukum dan Masyarakat

Soemitro, Ronny Hanitijo, Metodelogi Penelitian Hukum, Ghalia, Jakarta, 2008.

Shubhan, M. Hadi, Hukum Kepailitan (Prinsip, Norma dan Praktik di Peradilan, Kencana, Prenada Media Group, Jakarta, 2008

Suci, Ivida Dewi Amrih dan Herowati Poesoko, Hukum Kepailitan Kedudukan dan Hak Kreditor Separatis atas Benda Jaminan Deitor Pailit, LaksBang Pressindo, Yogyakarta, 2016

Sunarmi, Hukum Kepailitan, USU Press, Medan, 2009.

; Hukum Kepailitan Edisi 2, Sofmedia, Jakarta, 2010.

Suparman, Man dan Endang, Hukum Asuransi: Perlindungan Tertanggung Asuransi Deposito Usaha Perasuransian, Alumni, Bandung, 2007.

Supramono, Gatot , Hukum Perseroan Terbatas, Djambatan, Jakarta, 2009

Sutedi, Adrian, Segi-Segi Hukum Pasar Modal, Ghalia, Jakarta, 2008.

Sjahdeini, Sutan Remy, Hukum Kepailitan Memahami Undang-Undang No. 37 Tahun 2004 Tentang Kepailitan, Pustaka Utama Grafiti, Jakarta, 2010

Tanya, Bernard L. Yoan N. Simanjuntak, dan Markus Y. Hage, Teori Hukum, Strategi Tertib Manusia Lintas Ruang dan Generasi, Genta Publishing, Yogyakarta , 2010.

Tengker, F. Hukum Suatu Pendekatan Elementer, Nova, Bandung, 1993

Triwulan, Titik dan Shinta Febrian, Perlindungan Hukum bagi Pasien, Prestasi Pustaka, Jakarta, 2010

Widodo, Segi Hukum Penyelesaian Perselisihan Perburuhan, Rajawali Pers, Jakarta, 2009

Wiriadinata, Wahyu, Masalah Penyidik Dalam Tindak Pidana Jasa Keuangan Di Indonesia, Pusat Litbang Kejaksaan Agung R.I, Jakarta, 2012
Wijayanta. Tata, Asas Kepastian Hukum, Keadilan Dan Kemanfaatan Dalam Kaitannya Dengan Putusan Kepailitan Pengadilan Niaga, Jurnal Hukum Fakultas Hukum Universitas Gadjah Mada, Yogyakarta, 2015

Yuhassarie, Emmy Undang-Undang Kepailitan dan Perkembangannya, Pusat Pengkajian Hukum, Jakarta, 2004

\section{B. Peraturan Perundang-undangan}

Undang-Undang Dasar Tahun 1945.

Kitab Undang-Undang Hukum Perdata.

Undang-Undang Nomor 37 Tahun 2004 tentang Kepailitan dan Penundaan Kewajiban Pembayaran Utang.

Undang-Undang Nomor 40 Tahun 2014 tentang Perasuransian.

Undang-Undang Nomor 21 Tahun 2011 Tentang Otoritas Jasa Keuangan.

\section{Artikel/Makalah/Jurnal/Internet}

Jurnal Hukum dan Pasar Modal vol V,Edisi 6/2013.

Kiryanto, Ryan, OJK dan Kepentingannya, Kompas, Jakarta, 14 Juni 2013.

Nasution, Bismar, "OJK Sebagai Suatu Sistem Hukum Dalam Pembangunan Ekonomi",Makalah disampaikan pada Seminar tentang Keberadaan Otoritas Jasa Keuangan untuk mewujudkan perkonomian nasional yang berkelanjutan dan stabil, Medan, 25 November 2014.

, "Struktur Regulasi Independensi Otoritas Jasa Keuangan" (Medan : Makalah disampaikan pada Seminar Hukum Peran dan Tujuan Otoritas Jasa Keuangan Ikatan Hukum Ekonomi Fakultas Hukum Universitas Sumatera Utara, Medan, 2013

Sitompul, Zulkarnain, "Fungsi dan Tugas Otoritas Jasa Keuangan dalam menjaga stabilitas Sistem Keuangan," disampaikan pada Seminar tentang Keberadaan Otoritas Jasa Keuangan 
Media Komunikasi dan Informasi Hukum dan Masyarakat

untuk Mewujudkan Perkonomian

Nasional yang Berkelanjutan dan

Stabil, Medan, 25 November 2014.

Syahmi, Afika Yumya, Pengaruh Pembentukan

Pengawasan Lembaga Perbankan

Suatu Kajian Terhadap Undang-

Undang Otoritas Jasa Keuangan, Jurnal, Fakultas Hukum Universitas Indonesia, Depok, 2004.

Syamsudin, Amir, Analisis Putusan Mahkamah Konsititusi tentang Kepailitan, Jurnal Konstitusi, Vol. 2 Nomor 2, September, 2017.

Tejaningsih, Ttitik, Perlindungan Hukum Terhadap Kreditor Separatis dalam Pengurusan dan Pemberasan Harta Pailit, Program Doktor (S-3) IImu Hukum Program Pascasarjana Fakultas Hukum Universitas Islam Indonesia, Yogyakarta, 2015. 